University of New Hampshire

University of New Hampshire Scholars' Repository

$9-16-2006$

\title{
Evaluation of the SeaWinds scatterometer for regional monitoring of vegetation phenology
}

\author{
Steve Frolking \\ University of New Hampshire - Main Campus, steve.frolking@unh.edu \\ Tom Milliman \\ University of New Hampshire - Main Campus \\ Kyle McDonald \\ California Institute of Technology \\ John Kimball \\ University of Montana, Missoula \\ Maosheng Zhao \\ University of Montana, Missoula
}

See next page for additional authors

Follow this and additional works at: https://scholars.unh.edu/earthsci_facpub

\section{Recommended Citation}

Frolking, S., T. Milliman, K. McDonald, J. Kimball, M. Zhao, and M. Fahnestock (2006), Evaluation of the SeaWinds scatterometer for regional monitoring of vegetation phenology, J. Geophys. Res., 111, D17302, doi:10.1029/2005JD006588.

This Article is brought to you for free and open access by the Earth Sciences at University of New Hampshire Scholars' Repository. It has been accepted for inclusion in Earth Sciences Scholarship by an authorized administrator of University of New Hampshire Scholars' Repository. For more information, please contact Scholarly.Communication@unh.edu. 


\section{Authors}

Steve Frolking, Tom Milliman, Kyle McDonald, John Kimball, Maosheng Zhao, and Mark Fahnestock 


\title{
Evaluation of the SeaWinds scatterometer for regional monitoring of vegetation phenology
}

\author{
Steve Frolking, ${ }^{1}$ Tom Milliman, ${ }^{1}$ Kyle McDonald, ${ }^{2}$ John Kimball, ${ }^{3,4}$ Maosheng Zhao, ${ }^{4}$ \\ and Mark Fahnestock, ${ }^{1}$ \\ Received 14 August 2005; revised 5 January 2006; accepted 20 April 2006; published 1 September 2006.
}

[1] Phenology, or the seasonality of recurring biological events such as vegetation canopy development and senescence, is a primary constraint on global carbon, water and energy cycles. We analyzed multiseason Ku-band radar backscatter measurements from the SeaWinds-on-QuikSCAT scatterometer to determine canopy phenology and growing season vegetation dynamics from 2000 to 2002 at 27 sites representing major global land cover classes and regionally across most of North America. We compared these results with similar information derived from the MODIS leaf area index (LAI) data product (MOD-15A2). In site-level linear regression analysis, the correspondence between radar backscatter and LAI was significant $(\mathrm{p}<0.05)$ at most but not all sites and was generally higher $\left(\mathrm{R}^{2}>0.5\right)$ for sites with relatively low LAI or where the seasonal range in LAI was large (e.g., $>3 \mathrm{~m}^{2} \mathrm{~m}^{-2}$ ). The SeaWinds instrument also detected generally earlier onset of vegetation canopy growth in spring than the optical/near-infrared (NIR) based LAI measurements from MODIS, though the timing of canopy senescence and the end of the growing season were more similar. Over North America, the correlation between the two time series was stratified largely by land cover class, with higher correlations ( $\mathrm{R} \sim 0.7-0.9$ ) for most cropland, deciduous broadleaf forest, crop/natural vegetation mosaic land cover, and some grassland. Lower correlations were observed for open shrubland and evergreen needleleaf forest. Overall, the results indicate that SeaWinds backscatter is sensitive to growing season canopy dynamics across a range of broadleaf vegetation types and provides a quantitative view that is independent of optical/NIR remote sensing instruments.

Citation: Frolking, S., T. Milliman, K. McDonald, J. Kimball, M. Zhao, and M. Fahnestock (2006), Evaluation of the SeaWinds scatterometer for regional monitoring of vegetation phenology, J. Geophys. Res., 111, D17302, doi:10.1029/2005JD006588.

\section{Introduction}

[2] Vegetation phenology describes the timing of seasonal developmental stages including bud burst, canopy growth, and senescence [Lechowicz, 2001]. Canopy phenology and associated landscape vegetation seasonal dynamics are a primary constraint on global carbon, water and energy cycles, because of the major influence of plant photosynthesis on land-atmosphere $\mathrm{CO}_{2}$ exchange [e.g., Keeling et al., 1989], and canopy albedo and transpiration on latent and sensible energy partitioning and regional weather [e.g., Fitzjarrald et al., 2001]. Broad-scale spatial and temporal variability in global phenology is largely determined by

\footnotetext{
${ }^{1}$ Institute for the Study of Earth, Oceans and Space, University of New Hampshire, Durham, New Hampshire, USA.

${ }^{2}$ Jet Propulsion Laboratory, California Institute of Technology, Pasadena, California, USA.

${ }^{3}$ Flathead Lake Biological Station, Division of Biological Sciences, University of Montana, Missoula, Montana, USA.

${ }^{4}$ Numerical Terradynamic Simulation Group, University of Montana, Missoula, Montana, USA.

Copyright 2006 by the American Geophysical Union. 0148-0227/06/2005JD006588
}

environmental limitations to plant growth, including photoperiod, available moisture and temperature [Nemani et al., 2003]. Vegetation phenology can also be spatially and temporally heterogeneous because of complex land cover, topographic and environmental gradients, with impacts on annual plant productivity, and carbon, water and energy cycles.

[3] Space-borne remote sensing is the only practical tool for global measurement and monitoring of seasonal vegetation dynamics at high temporal and moderate spatial resolution. Satellite remote sensing of vegetation phenology has generally been the domain of optical instruments, including the Advanced Very High Resolution Radiometer (AVHRR) and Moderate Resolution Imaging Spectroradiometer (MODIS), because of frequent sampling and nearglobal coverage of these sensors and strong sensitivity of visible and near-infrared wavelengths to photosynthetic biomass [e.g., Tucker, 1979; Sellers, 1985]. Available products from these sensors include global and continental maps of vegetation greenness (e.g., Normalized Difference Vegetation Index or NDVI and Enhanced Vegetation Index or EVI), leaf area index (LAI), and seasonal phenology [e.g., Goward et al., 1985; White et al., 1997; Myneni et al., 1998; 
Moulin et al., 1997; Jenkins et al., 2002; Zhang et al., 2004] and, coupled with ecosystem models, vegetation productivity [e.g., Myneni et al., 1997; Tucker et al., 2001; Hicke et al., 2002; Nemani et al., 2003; Potter et al., 2003; Slayback et al., 2003]. However, satellite based monitoring of vegetation activity at optical and near-infrared wavelengths is compromised by cloud cover, smoke and aerosol contamination over much of the globe, and requires relatively coarse (8-16 day) temporal compositing of the data to reduce atmospheric effects. Seasonal snow cover, low solar illumination and solar elevation angles also limit vegetation monitoring at high latitudes, especially during the growing season margins when vegetation changes are large (e.g., bud-burst and canopy growth and senescence) [Cihlar et al., 1998; Vermote et al., 2002; Zhao et al., 2005].

[4] Satellite microwave remote sensing has been used for landscape- to global-scale assessments of a variety of biophysical parameters including soil moisture [e.g., Magagi and Kerr, 1997; Wagner et al., 1999a; Wagner and Scipal, 2000], snow cover [e.g., Nghiem and Tsai, 2001], freeze/ thaw state [e.g., Wismann, 2000; Kimball et al., 2004a, 2004b; McDonald et al., 2004; McDonald and Kimball, 2005; Rawlins et al., 2005], and vegetation dynamics [e.g., Frison and Mougin, 1996; Magagi and Kerr, 1997; Hardin and Jackson, 2003]. Radar sensitivity to these parameters arises from the strong dependence of radar backscatter to surface dielectric properties, which are strongly dependent upon the liquid water content of the landscape. Shorter microwave wavelengths (e.g., $\mathrm{Ku}$ - and $\mathrm{C}$-band) are particularly sensitive to the vegetation canopy structure and moisture because of the similar characteristic sizes of leaves and branches, which increases the radar backscatter response to these canopy constituents [Ulaby et al., 1982; Elachi, 1987]. Microwave radar remote sensing instruments illuminate the land surface independent of solar radiation, and are largely insensitive to cloud cover, smoke and other atmospheric aerosols. Satellite radar remote sensing thus has the potential for nearly continuous global monitoring, day or night and under virtually all weather conditions, with monitoring capabilities constrained primarily by sensor design and orbital geometry. Current satellite scatterometers provide approximate daily global coverage at $\sim 25-\mathrm{km}$ spatial resolution, with greater sampling frequency at higher latitudes. Image reconstruction techniques can be employed to enhance spatial resolution at the expense of temporal resolution [Early and Long, 2001].

[5] Frison and Mougin [1996] analyzed monthly ERS-1 C-band $(f=5.3 \mathrm{GHz}, \lambda=5.7 \mathrm{~cm})$ backscatter and AVHRR Global Area Coverage (GAC) Global Vegetation Index (GVI) data from spring 1992 through spring 1994 for 17 sites $(\sim 50 \mathrm{~km} \times 50 \mathrm{~km})$ distributed globally; they found that seasonality in radar backscatter and the GVI was well correlated for most sites, with semiarid and boreal regions showing the largest seasonality in radar backscatter and environmental parameters (i.e., moisture and temperature, respectively). Abdel-Messeh and Quegan [2000] evaluated ERS scatterometer backscatter data globally and found strong backscatter temporal variability for several vegetation classes. They attributed grassland backscatter variability to changes in plant phenology, soil moisture, snow and freeze/thaw processes, and agricultural practices. They attributed savanna backscatter variability to rainfall events and vegetation growth. They attributed northern highlatitude variability to snowfall and snowmelt processes. Both of these studies showed relatively little seasonal backscatter variability in tropical forests. Wagner et al. [1999b] evaluated ERS-1 scatterometer data across the Iberian Peninsula and found that radar backscatter dependence on sensor incidence angle showed a seasonal pattern for crops and grasslands, but not for forests, shrubs, and arid land vegetation; they concluded that backscatter temporal variability was more strongly associated with soil moisture than vegetation dynamics. Woodhouse et al. [1999] found a small seasonal amplitude $(0.6 \mathrm{~dB})$ in ERS-1 scatterometer backscatter for a $50 \mathrm{~km} \times 50 \mathrm{~km}$ tropical rain forest site in Guyana that was correlated with monthly precipitation; the correlation was not evident at shorter timescales, which may reflect the spatial scale discrepancy between local weather station (point) and scatterometer (area-average) data.

[6] Hardin and Jackson [2003] analyzed year 2000 SeaWinds Ku-band $(f=13.4 \mathrm{GHz}, \lambda=2.24 \mathrm{~cm})$ data for relatively intact equatorial savanna grassland sites (areas 180,000 to $530,000 \mathrm{~km}^{2}$ ) in northern South America. For each site, they constructed (1) monthly mean backscatter for both horizontal $(\mathrm{HH})$ and vertical $(\mathrm{VV})$ polarizations standardized to a $50^{\circ}$ incidence angle, (2) mean AVHRR NDVI, and (3) mean air temperature and total precipitation time series. They also quantified the fractional cover of Gleysol and Ferralsol soil types for each site. They found that the $\mathrm{Ku}$-band backscatter for both polarizations was well correlated with the NDVI $(\mathrm{R}=0.52-0.74)$, with a stronger correspondence for the site with the largest NDVI. The correlations were improved somewhat by adding precipitation and soil type in a multiple linear regression, while air temperature had no significant impact on the correlation for these tropical sites.

[7] In this paper we extend the analysis of Hardin and Jackson [2003] in five ways. First, we analyze the relationship between SeaWinds backscatter and MODIS (MOD-15) LAI 8-day time series across a wide range of global vegetation types and geographical locations. Second, we analyze multiyear (2000-2002) data to determine if LAI and radar backscatter show similar variability over multiple growing seasons. Third, we extract and compare phenological timing signals (spring leaf flush and fall leaf senescence) from both data series. Fourth, we use the Michigan Microwave Canopy Scattering radar backscatter model (MIMICS) [Ulaby et al., 1990] to interpret the Ku-band backscatter seasonal response to canopy LAI and vegetation and surface moisture. Fifth, we conduct a regional analysis of North America to determine if there are coherent spatial patterns in the correlation between Ku-band backscatter and LAI. Our objective is to evaluate the potential for SeaWinds backscatter to detect vegetation phenology, as a necessary first step before attempting to develop a robust and reliable phenology algorithm.

\section{Methods}

\subsection{Site-Level Analysis}

[8] We selected 27 sites spanning a range of global land cover types, each representing a $50 \mathrm{~km} \times 50 \mathrm{~km}$ area with relatively homogeneous vegetation cover $(>80 \%$ classified as a single vegetation class). We defined vegetation cover 
Table 1. Location and Dominant Vegetation of the 27 Sites, Range of Remote Sensing Observations (2000-2002), and Linear Regression Statistics

\begin{tabular}{|c|c|c|c|c|c|c|c|c|}
\hline Site $^{\mathrm{a}}$ & Location & $\begin{array}{l}\text { MODIS LAI Range, } \\
\mathrm{m}^{2} \mathrm{~m}^{-2}\end{array}$ & $\begin{array}{c}\text { Seawinds } \sigma^{\circ} \text { Range, }{ }^{\mathrm{b}} \\
\mathrm{dB}\end{array}$ & $\mathrm{R}^{2}$ & $p$ Value & $a_{1}$ & $a_{2}$ & $N^{\mathrm{c}}$ \\
\hline EB-1 & S. America $\left(7.0^{\circ} \mathrm{S}, 67.0^{\circ} \mathrm{W}\right)$ & $5.0-6.5$ & -9.7 to -8.8 & 0.00 & 0.718 & -9.31 & 0.02 & 128 \\
\hline EB-2 & S. America $\left(1.0^{\circ} \mathrm{S}, 70.0^{\circ} \mathrm{W}\right)$ & $5.0-6.0$ & -9.3 to -8.2 & 0.01 & 0.425 & -8.40 & -0.07 & 128 \\
\hline EB-3 & Africa $\left(0.5^{\circ} \mathrm{S}, 24.5^{\circ} \mathrm{E}\right)$ & $4.6-6.5$ & -9.0 to -8.0 & 0.00 & 0.558 & -8.33 & -0.03 & 127 \\
\hline EB-4 & Asia $\left(2.0^{\circ} \mathrm{N}, 114.5^{\circ} \mathrm{E}\right)$ & $4.3-5.9$ & -8.5 to -7.7 & 0.00 & 0.724 & -8.02 & -0.01 & 128 \\
\hline EN-1 & N. America $\left(53.0^{\circ} \mathrm{N}, 124.0^{\circ} \mathrm{W}\right)$ & $2.0-3.7$ & -14.4 to -13.2 & 0.13 & 0.011 & -14.52 & 0.22 & 51 \\
\hline EN-2 & N. America $\left(47.5^{\circ} \mathrm{N}, 115.5^{\circ} \mathrm{W}\right)$ & $1.8-4.7$ & -13.5 to -12.6 & 0.69 & $<0.001$ & -13.71 & 0.22 & 59 \\
\hline EN-3 & Europe $\left(65.0^{\circ} \mathrm{N}, 18.0^{\circ} \mathrm{E}\right)$ & $1.8-3.9$ & -14.1 to -12.5 & 0.14 & 0.004 & -13.86 & 0.23 & 57 \\
\hline EN-4 & N. America $\left(54.0^{\circ} \mathrm{N}, 118.0^{\circ} \mathrm{W}\right)$ & $1.6-3.4$ & -14.1 to -12.8 & 0.23 & $<0.001$ & -14.20 & 0.29 & 51 \\
\hline DN-1 & Asia $\left(61.5^{\circ} \mathrm{N}, 132.0^{\circ} \mathrm{E}\right)$ & $0.8-4.6$ & -13.6 to -12.0 & 0.19 & 0.003 & -13.00 & 0.13 & 44 \\
\hline DB-1 & N. America $\left(41.5^{\circ} \mathrm{N}, 78.5^{\circ} \mathrm{W}\right)$ & $1.2-6.1$ & -11.6 to -10.0 & 0.35 & $<0.001$ & -11.49 & 0.14 & 76 \\
\hline DB-2 & N. America $\left(39.5^{\circ} \mathrm{N}, 81.0^{\circ} \mathrm{W}\right)$ & $1.0-6.2$ & -12.1 to -9.4 & 0.75 & $<0.001$ & -11.97 & 0.33 & 92 \\
\hline MF-1 & N. America $\left(52.0^{\circ} \mathrm{N}, 83.5^{\circ} \mathrm{W}\right)$ & $2.0-4.9$ & -13.4 to -11.9 & 0.12 & 0.014 & -13.26 & 0.14 & 50 \\
\hline MF-2 & N. America $\left(58.5^{\circ} \mathrm{N}, 118.0^{\circ} \mathrm{W}\right)$ & $1.5-5.0$ & -13.0 to -11.4 & 0.48 & $<0.001$ & -12.86 & 0.23 & 53 \\
\hline MF-3 & Asia $\left(59.0^{\circ} \mathrm{N}, 62.0^{\circ} \mathrm{E}\right)$ & $2.2-5.9$ & -13.0 to -11.2 & 0.36 & $<0.001$ & -12.81 & 0.21 & 54 \\
\hline MF-4 & Asia $\left(59.5^{\circ} \mathrm{N}, 108.5^{\circ} \mathrm{E}\right)$ & $1.4-4.7$ & -13.4 to -12.2 & 0.13 & 0.016 & -13.23 & 0.12 & 44 \\
\hline WS-1 & Africa $\left(5.0^{\circ} \mathrm{N}, 27.5^{\circ} \mathrm{E}\right)$ & $1.3-4.6$ & -10.8 to -8.4 & 0.81 & $<0.001$ & -11.36 & 0.60 & 127 \\
\hline WS-2 & Australia $\left(25.5^{\circ} \mathrm{S}, 147.5^{\circ} \mathrm{E}\right)$ & $0.7-1.7$ & -13.9 to -12.0 & 0.01 & 0.171 & -13.35 & 0.22 & 130 \\
\hline $\mathrm{SH}-1$ & Africa $\left(26.0^{\circ} \mathrm{S}, 21.5^{\circ} \mathrm{E}\right)$ & $0.2-0.6$ & -17.3 to -13.9 & 0.57 & $<0.001$ & -17.92 & 8.34 & 127 \\
\hline $\mathrm{SH}-2$ & Australia $\left(28.0^{\circ} \mathrm{S}, 146.5^{\circ} \mathrm{E}\right)$ & $0.3-0.8$ & -16.0 to -13.5 & 0.4 & $<0.001$ & -16.63 & 3.03 & 130 \\
\hline $\mathrm{SH}-3$ & N. America $\left(64.5^{\circ} \mathrm{N}, 104.5^{\circ} \mathrm{W}\right)$ & $0.8-1.9$ & -16.0 to -14.1 & 0.02 & 0.427 & -15.10 & 0.20 & 34 \\
\hline SH-4 & $\mathrm{N}$. America $\left(40.5^{\circ} \mathrm{N}, 117.5^{\circ} \mathrm{W}\right)$ & $0.2-0.6$ & -14.0 to -12.2 & 0.24 & $<0.001$ & -12.21 & -2.37 & 79 \\
\hline SV-1 & Africa $\left(9.5^{\circ} \mathrm{N}, 3.0^{\circ} \mathrm{E}\right)$ & $0.7-4.4$ & -12.3 to -9.4 & 0.79 & $<0.001$ & -12.10 & 0.59 & 128 \\
\hline SV-2 & S. America $\left(4.5^{\circ} \mathrm{S}, 41.0^{\circ} \mathrm{W}\right)$ & $0.7-3.7$ & -11.4 to -10.0 & 0.34 & $<0.001$ & -11.16 & 0.17 & 128 \\
\hline GR-1 & N. America $\left(36.0^{\circ} \mathrm{N}, 100.5^{\circ} \mathrm{W}\right)$ & $0.2-1.1$ & -17.1 to -14.0 & 0.54 & $<0.001$ & -16.60 & 2.44 & 94 \\
\hline GR-2 & N. America $\left(45.5^{\circ} \mathrm{N}, 102.5^{\circ} \mathrm{W}\right)$ & $0.2-1.3$ & -18.6 to -14.4 & 0.66 & $<0.001$ & -18.37 & 3.28 & 72 \\
\hline GR-3 & N. America $\left(47.5^{\circ} \mathrm{N}, 117.0^{\circ} \mathrm{E}\right)$ & $0.2-1.2$ & -21.8 to -14.3 & 0.78 & $<0.001$ & -20.96 & 6.53 & 58 \\
\hline GR-4 & Asia $\left(49.0^{\circ} \mathrm{N}, 57.5^{\circ} \mathrm{E}\right)$ & $0.2-0.9$ & -18.4 to -13.7 & 0.27 & $<0.001$ & -17.11 & 1.92 & 64 \\
\hline
\end{tabular}

${ }^{a}$ Vegetation class occupies more than $80 \%$ of $50 \mathrm{~km} \times 50 \mathrm{~km}$ site. EB, evergreen broadleaf; EN, evergreen needleleaf; DN, deciduous needleleaf; DB, deciduous broadleaf; MF, mixed forest; SH, shrub; WS, woody savanna; SV, savanna; and GR, grass.

${ }^{\mathrm{b}}$ Thawed season values only (see section 2.1.3).

${ }^{\mathrm{c}}$ Number of 8-day composites passing temperature threshold test (see section 2.1.3).

using a MODIS (v.3) 1-km resolution global land cover map [Friedl et al., 2002]. The sites, located on all continents except Antarctica, represented 9 vegetation classes; each vegetation class except deciduous needleleaf forest was represented by at least two sites (Table 1). For each site, we investigated the correlation between SeaWinds radar backscatter $\left(\sigma^{\circ}\right)$ and MODIS-derived LAI during nonfrozen periods from 2000-2002. We also fit a set of logistical curves [Zhang et al., 2003, 2004] to the rise and fall of the seasonal backscatter and LAI to derive the timing of leaf flush and leaf senescence, respectively, from each instrument time series data.

\subsubsection{MODIS Leaf Area Index Data}

[9] LAI data for each site were extracted from the MOD15A2 8-day composite (v.4), 1-km resolution LAI product (edcdaac.usgs.gov/modis/mod15a2.asp). LAI values flagged as contaminated by cloud, snow, or aerosols [Myneni et al., 2002] were removed, and the remaining values (i.e., those with good quality assessment) were linearly interpolated to fill gaps [Zhao et al., 2005]. The $25001-\mathrm{km}$ values at each 8-day time step in each $50 \mathrm{~km} \times$ $50 \mathrm{~km}$ site were averaged to derive a single LAI time series for each site.

\subsubsection{SeaWinds Backscatter Data}

[10] For this investigation we used daily Ku-band backscatter measurements from SeaWinds-on-QuikSCAT to classify growing season parameters from 2000 to 2002 . The SeaWinds instrument consists of a rotating pencil-beam antenna, which provides contiguous measurement swaths of
$1400 \mathrm{~km}$ (inner beam) and $1800 \mathrm{~km}$ (outer beam), coverage of approximately $70 \%$ of the Earth on a daily basis and $90 \%$ global coverage every 2 days. At higher latitudes (i.e., $>40^{\circ} \mathrm{N}$ ) SeaWinds temporal coverage is improved, often allowing for multiple radar backscatter measurements per unit land area per day. The instrument has mean incidence angles of $54^{\circ}$ (outer beam; VV polarization) and $46^{\circ}$ (inner beam; HH polarization). The Level $2 \mathrm{~A}$ "egg" data product has spatial resolution of approximately $37 \times 25 \mathrm{~km}$. The SeaWinds radar transmits microwave radiation at $13.4 \mathrm{GHz}$ (2.24 cm wavelength) and receives a surface backscatter signal with a $0.25 \mathrm{~dB}$ relative accuracy [King and Greenstone, 1999].

[11] Utilizing the L2A data product, we extracted SeaWinds outer beam radar backscatter measurements for each study site, beginning 1 January 2000 and extending through 31 December 2002. All daily SeaWinds "egg" data with center locations within a $10-\mathrm{km}$ radius centered over each study site were extracted and averaged on an orbit-by-orbit basis. Because of its wider swath, SeaWinds outer beam data provide improved temporal coverage (i.e., up to 5 or more samples per day at high latitudes) relative to inner beam data. The larger incidence angle of the outer beam data also provides an increased propagation path through the vegetation volume and may, in some instances, increase backscatter sensitivity to vegetation structure and moisture relative to inner beam data. Hardin and Jackson [2003] found SeaWinds $\mathrm{HH}$ and VV polarization responses to be similar in their savanna study. The orbit-by-orbit backscatter 
values were averaged to the same 8-day intervals as the MODIS LAI data using an 8-day windowing scheme. Mean backscatter and backscatter variances were computed for each 8-day interval.

\subsubsection{Daily Weather Data}

[12] Daily maximum and minimum air temperature data were taken from the NASA Data Assimilation Office (DAO) 3-hour reanalysis data set [Data Assimilation Office, 2002], and nonlinear spatial smoothing was used to interpolate the $1^{\circ} \times 1.25^{\circ}$ data to each site [Zhao et al., 2005]. These data were used to stratify the annual radar time series into frozen and thawed seasons, and particularly to filter out the dynamic backscatter temporal response to snow and landscape freeze/thaw effects. The onset of fully thawed conditions was determined, through visual inspection of the data, to occur after seven consecutive days with mean air temperatures greater than $4^{\circ} \mathrm{C}$. The end of the thawed season was identified as the first day with mean air temperatures less than $3^{\circ} \mathrm{C}$. To avoid multiple transition dates between seasons when average temperatures hovered near the threshold, transition dates were required to be at least 60 days apart. Of the 27 sites, 17 had an identified frozen season in which the backscatter signal was masked out. We also refer to this thawed period as the growing season, though some photosynthesis will occur during the freezethaw transition period, particularly for evergreen systems, and for drought-deciduous systems vegetation can be dormant during some thawed periods.

\subsubsection{Site-Level Correlation of Microwave Backscatter and LAI}

[13] We used linear regression to calculate correlations between the growing season SeaWinds backscatter $\left(\sigma^{\circ}\right)$ and MODIS LAI data for each site, of the form

$$
\sigma_{i}^{o}=a_{1 i}+a_{2 i} \cdot L A I_{i}
$$

where $a_{1 i}$ and $a_{2 i}$ are the regression parameters for site $i$. We used all 3 years of data in a single correlation analysis for each site. This analysis returned coefficients of determination ( $\mathrm{R}^{2}$ and $p$ value) and values for the two regression coefficients, $a_{1 i}$ and $a_{2 i}$, for each site.

\subsubsection{Site-Level Phenological Timing Analysis}

[14] Following the methodology of Zhang et al. [2003], we fit a curve of the form

$$
y_{i}=\frac{c_{i}}{1+e^{a_{i}+b_{i} t}}+d_{i}
$$

to the seasonal increase (spring) and to the seasonal decrease (autumn) of each growing season's $\sigma^{\circ}$ and LAI data in the multiyear time series, where $y_{i}$ is either $\sigma^{\circ}$ or LAI for site $i, t$ is day of year, and $a_{i}, b_{i}, c_{i}$, and $d_{i}$ are fitting parameters for site $i$. For this analysis we further constrained the logistical function by fixing $c_{i}$ and $d_{i}$ for each site $\left(c_{i}=\right.$ minimum value in 50 days prior to growing season, $c_{i}+d_{i}=$ maximum growing season LAI or 32-day mean of $\sigma^{\circ}$ values, centered on the peak value) resulting in a twoparameter fit for $a_{i}$ and $b_{i}$. We determined best fit values for these coefficients using least squares estimation. We determined the midpoints (points of steepest rise and steepest descent) in the rise ("leaf-flush") and fall ("senescence") of the curve fits (equation (2)) to the $\sigma^{\circ}$

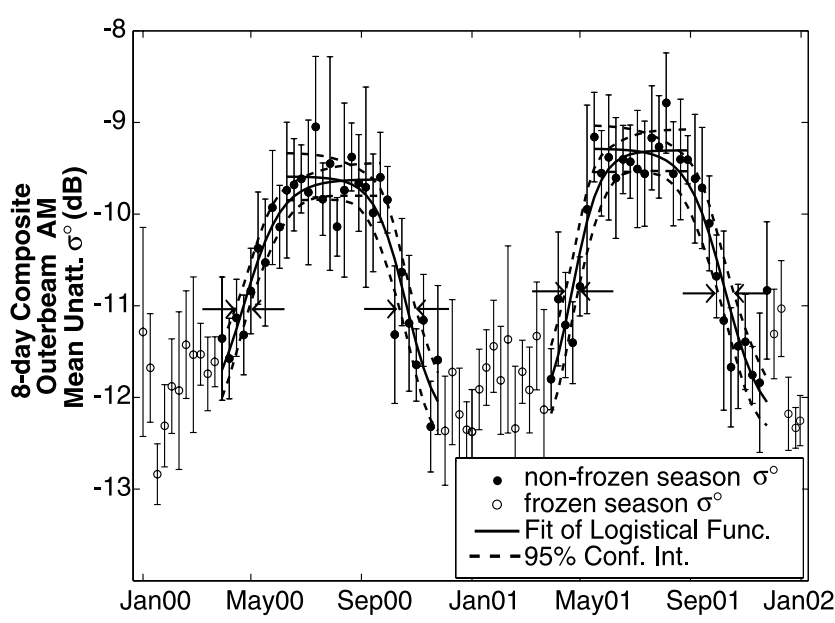

Figure 1. Two-year time series of observed 8-day composite SeaWinds backscatter $\sigma^{\circ}$ (frozen season indicated by open symbols and thawed season indicated by solid symbols) for a single site (DB-2; see Table 1), spring and fall curves fit to the data (see equation (2); solid lines), and $95 \%$ confidence intervals (dashed lines). Horizontal arrows in spring and fall of each year indicate uncertainty around estimates of phenological timing of midpoint of rise and fall of backscatter. See section 2.1.5 for methodological details.

and LAI data (Figure 1). From the 95\% confidence intervals around these fits, we calculated an uncertainty in this phenological timing (Figure 1).

\subsection{Theoretical Backscatter Analysis}

[15] Physically based radar backscatter models are useful for coupling land surface physical properties to backscatter signatures, providing a powerful means for interpretation of remote sensing data. The MIMICS model [Ulaby et al., 1990; Ulaby and Elachi, 1990; McDonald and Ulaby, 1993] was used to examine theoretical backscatter sensitivity to leaf area index (LAI), soil moisture, and vegetation moisture for selected structural classes of canopies.

[16] For purposes of modeling microwave backscatter, MIMICS characterizes a vegetation canopy as a discrete random medium consisting of one or two layers of vegetation over a rough ground surface. The two-layer model is often used for deciduous trees and in conifers where a clear boundary between the crown and trunk layers can be identified. The top (crown) layer consists of randomly distributed branches and leaves. The bottom (trunk) layer consists of the tree trunks, usually oriented in a near-vertical fashion. The single layer model is generally applied to canopies with simpler structures, such as grasslands, shrublands, and croplands [Ulaby et al., 1990; Ulaby and Elachi, 1990]. Canopy constituents (leaves, needles, branches, trunks) are considered as discrete scatterers, and are modeled by lossy dielectric canonical geometries such as discs and circular cylinders. These elements are described in terms of their probability distributions in size and orientation, their number density (constituents per unit volume or area), and their dielectric constant. Soil and vegetation dielectric properties are estimated by models relating moisture parameters to microwave dielectric constant. The 
scattering and extinction properties of individual components are obtained through application of scattering models appropriate to the sizes of the scatterer relative to the sensor wavelength. The underlying ground is modeled as a homogeneous dielectric half-space with a roughness described by the RMS surface roughness and correlation length. MIMICS has been established as an effective microwave backscatter model for a wide range of radar sensor configurations and a variety of vegetation canopy architectures, including closed and open canopy structures [McDonald et al., 1990, 1991; McDonald and Ulaby, 1993; Rignot et al., 1994; Way et al., 1994].

[17] Four structural classes of vegetation canopies were considered in this analysis: (1) grassland, (2) deciduous broadleaf trees, and (3) high- and (4) low-biomass needleleaf trees. Parameters applied in characterizing broadleaf and needleleaf trees were based on parameter development in previous studies in which MIMICS had been evaluated against field data for several canopy structural classes over a variety of seasonal conditions, and for a variety of sensor configurations [Way et al., 1994]. The grassland canopy was modeled as leafy vegetation over a rough ground surface, and included no woody constituents [e.g., Du et al., 2000]. MIMICS was used to simulate backscatter for the SeaWinds outer beam configuration (14 GHz, VV-polarization, 54 ${ }^{\circ}$ incidence angle) for a variety of LAI values, canopy structures, and moisture conditions.

\subsection{Regional Analysis}

[18] To further evaluate the relationship between LAI and $\sigma^{\circ}$, we acquired multiyear gridded data sets over North America. We then evaluated the magnitude of Pearson's correlation coefficient (R) for 8-day composites of LAI and $\sigma^{\circ}$ for each grid cell.

\subsubsection{Regional SeaWinds Backscatter Data}

[19] We acquired January 2000 through December 2002 SeaWinds backscatter data $\left(\sigma^{\circ}\right.$ in $\left.\mathrm{dB}\right)$ for North America from the NASA Scatterometer Climate Record Pathfinder database maintained at Brigham Young University (http:// www.scp.byu.edu). We used the resolution enhanced Scatterometer Image Reconstruction (SIR) images derived from the L2A "egg" data, which incorporate both ascending and descending orbital passes and are a composite 4-day average backscatter time series [Early and Long, 2001]. The SIR technique for resolution enhancement was developed specifically for application to satellite-based scatterometer data. The technique utilizes multiple satellite passes to improve the spatial resolution of the backscatter over a temporal compositing interval, during which surface characteristics are assumed constant. The temporal compositing interval is restricted to support detection of short-term change; a tradeoff is therefore made between imaging time interval and spatial resolution. Multiple-pass SIR is not without some limitations, however, as temporal variability in target characteristics (structure or dielectric constant) during the imaging time interval can cause temporal smearing when multiple passes are combined [Early and Long, 1996]. The SeaWinds backscatter data set defined the spatial domain and resolution $(\sim 4.5 \mathrm{~km})$ of the regional analysis (see Figure 7 below). We temporally aggregated the 4-day backscatter product into an 8-day product by averaging the backscattered power.

\subsubsection{Regional MODIS Leaf Area Index and Land Cover Data}

[20] Mean 8-day composite LAI for 2000-2002 was taken from the MODIS MOD15A2 8-day 1-km LAI product (v.4) (http://delenn.gsfc.nasa.gov/ imswww/pub/ imswelcome/ [Myneni et al., 2002]). We did not interpolate to fill temporal or spatial gaps. For spatial aggregation, the central latitude-longitude of each 1-km MODIS pixel was identified within its associated SeaWinds grid cell. To reduce atmospheric contamination effects, we averaged only LAI values with a quality control flag $\leq 1$ (FparLai QC MODLAND bitfield), obtaining a single LAI value for each SeaWinds grid cell and 8-day composite during 2000-2002.

[21] We used the MODIS MOD12Q1 1-km land cover product (v.4) [Friedl et al., 2002] for North America, using the IGBP land cover legend with 18 cover types, to evaluate whether patterns in the backscatter-LAI correlation corresponded to vegetation cover. The $1-\mathrm{km}$ land cover product was reprojected and spatially composited to the SeaWinds grid $(\sim 4.5 \mathrm{~km})$, by identifying the dominant vegetation class in each grid cell and recording the fraction of the grid cell occupied by that dominant class. Only grid cells with an assessment confidence $\geq 50$ and with quality control $\leq 1$ (Land_Cover_Type_1_Assessment Mandatory QA bitfield) were included in this reprojection.

\subsubsection{Regional Daily Weather Data}

[22] To screen out frozen season data, we generated a temperature mask (see section 2.1.3) using the European Centre for Medium-range Weather Forecasting ERA-40 temperature fields for January 2000 through August 2002 (http://www.ecmwf.int/products/data/archive/). The 6-hourly temperature data were averaged to daily means, reprojected and spatially disaggregated to the same grid as the SeaWinds data by two-dimensional linear interpolation. This gridded daily temperature time series was then used to screen non-growing season periods, as in section 2.1.3. All LAI and SeaWinds data after August 2002 were excluded from the analysis, as we did not have ERA-40 temperature data to determine the end of the 2002 growing season.

\subsubsection{Grid Cell Correlation of Microwave Backscatter} and LAI

[23] We calculated linear correlations between the growing season SeaWinds backscatter, $\sigma^{\circ}$, and MODIS LAI data for each grid cell, $j$. We used all 3 years of data in a single correlation analysis for each site. This analysis returned correlation coefficients $(R)$ for each grid cell; these were mapped to look for coherent spatial patterns that could be related to land cover type.

\section{Results}

\subsection{Site Level Results}

[24] Across the 27 sites, thawed season LAI values from MODIS range from $<1 \mathrm{~m}^{2} \mathrm{~m}^{-2}$ in grassland and temperate/ subtropical shrub sites to $>5 \mathrm{~m}^{2} \mathrm{~m}^{-2}$ in wet tropical forest (all EB sites) year-round and in temperate broadleaf forest (both DB sites and the MF-3 site) during peak growing season (Table 1). Growing season SeaWinds backscatter values ranged from less than $-18 \mathrm{~dB}$ in three grassland sites to more than $-9 \mathrm{~dB}$ year-round in all wet tropical forest 


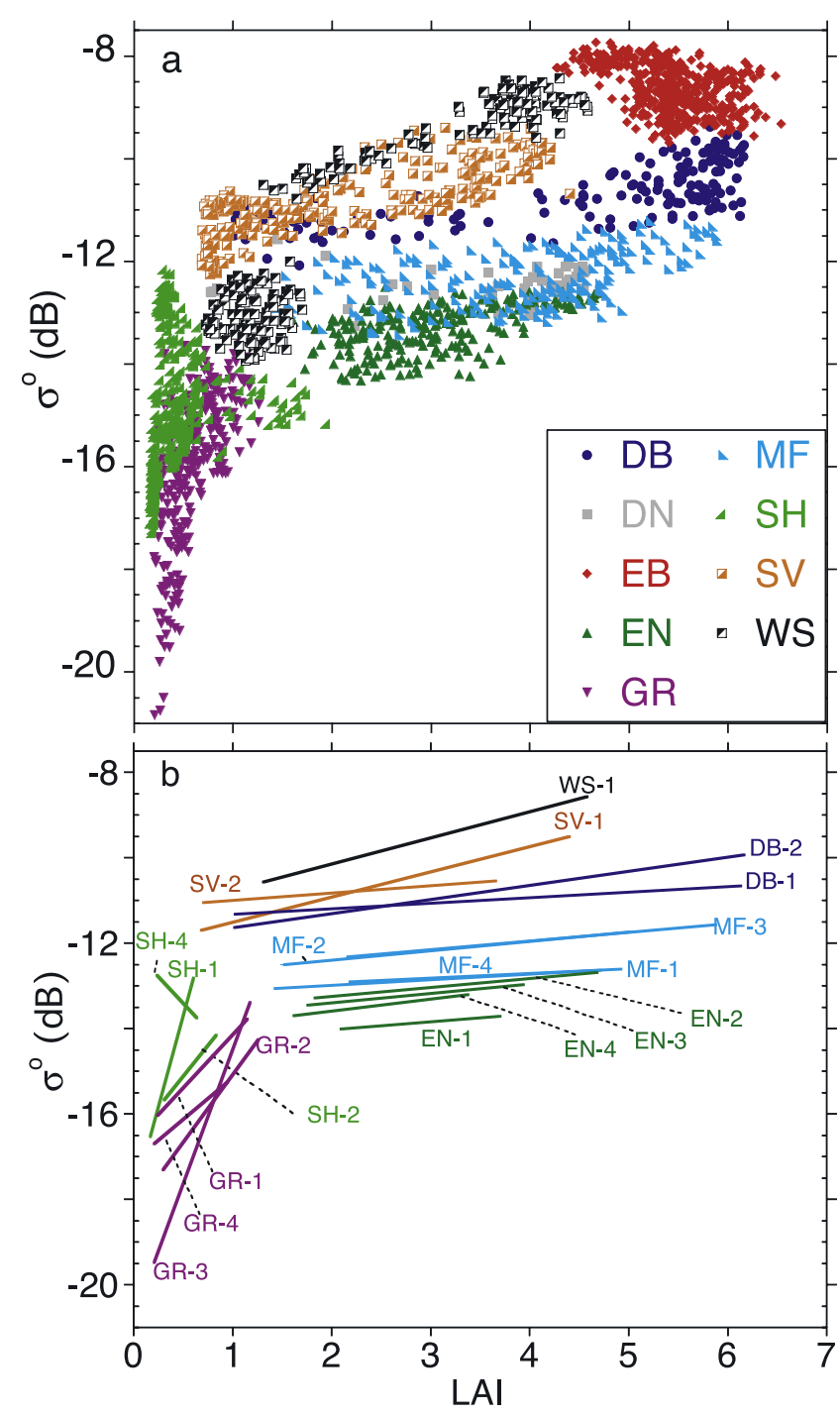

Figure 2. (a) Scatterplot of growing season 8-day composite $\sigma^{\circ}$ versus 8 -day composite LAI for all sites and all years, aggregated by vegetation class. (b) Linear regression lines (see equation (1) in text) for each site that had a regression $p$ value less than 0.05 (i.e., excluding sites EB-1, EB-2, EB-3, EB-4, WS-2, and SH-3). See Table 1 for site locations and site-level linear regression statistics. Note that all sites are $50 \mathrm{~km} \times 50 \mathrm{~km}$.

(EB) sites and during the peak growing season at the WS-1 site. There was an overall pattern across all sites of cooccurrence of low LAI correlating with low backscatter and high LAI with high backscatter; although the relationship was not linear across the entire domain (Figure 2a), it was generally linear for individual sites.

[25] Coefficients of determination between MODIS LAI and SeaWinds backscatter for the 27 sites ranged from 0.81 to 0.0 ; twenty-one of the sites had significant relationships between backscatter and LAI $(p<0.05)$, but only eight sites had $\mathrm{R}^{2}$ values greater than 0.5 (Table 1 ). Linear relationships were strong to moderate $\left(\mathrm{R}^{2} \geq 0.25\right)$ for all savanna, deciduous broadleaf, and grassland sites, as well as two mixed forest sites (MF-2 and MF-3), two shrub sites (SH-1 and $\mathrm{SH}-2$ ), an evergreen needleleaf site (EN-2), and a woody savanna site (WS-1) (Table 1). Linear relationships were weak to nonexistent $\left(\mathrm{R}^{2}<0.25\right)$ for all evergreen broadleaf sites, three evergreen needleleaf sites, the deciduous needleleaf site, as well as two mixed forest sites (MF-1 and MF-4), two shrub sites (SH 3 and SH-4), and a woody savanna site (WS-2) (Table 1).

[26] Grassland and shrub sites with significant relationships had maximum LAI values less than 1.5; these sites generally had strong backscatter dependence on LAI (regression slope greater than about $2 \mathrm{~dB}$ per LAI unit) (Figure $2 b$ ). The savanna, deciduous broadleaf, mixed forest sites and the WS-1 site all had a wide range in LAI values (minimum LAI generally less than 2, maximum LAI generally greater than 4); these sites all had a weaker backscatter dependence on LAI (regression slope less than about $0.6 \mathrm{~dB}$ per LAI unit) (Figure 2b). Among the 21 sites that had a significant correlation between MODIS LAI and SeaWinds backscatter $(\mathrm{p}<0.05$; see Table 1$)$, only the SH-4 site had a negative slope (equation (1) and Figure 2b), but the relationship was weak $\left(\mathrm{R}^{2}=0.24\right)$.

[27] To evaluate whether correspondence between MODIS LAI and SeaWinds backscatter data were sufficient to discriminate either distinct growing season patterns (e.g., asymmetries, double peaks, ...) or interannual differences in growing season dynamics, we used the site-level linear regressions (Table 1) to generate multiyear time series of simulated backscatter, with $95 \%$ confidence limits, from the MODIS LAI 8-day product. We selected 4 herbaceous sites and 4 woody sites with strong correlations (Figure 3: GR-1, GR-2, GR-3, SV-1, EN-2, DB-2, SH-1, and WS-1). All three grassland sites showed marked seasonal and interannual variability in radar backscatter that corresponded to variability in LAI. For GR-1, the seasonal radar backscatter curve in 2000 was relatively narrow and symmetric; in 2001 the backscatter progression rose high early and then had a lower plateau, while in the 2002 backscatter curve was broad and symmetric (Figure 3a). These basic patterns were also captured in the LAI-based estimate of the backscatter (Figure 3a). The GR-2 site had similar SeaWinds backscatter patterns in 2000 and 2001, but lower values and a less symmetric seasonal curve in 2002 (Figure 3b). The LAIbased estimate of the backscatter was less consistent between 2000 and 2001, but did have a lower and less symmetric pattern in 2002 (Figure 3b). The GR-3 site had a much higher and narrower growing season peak in backscatter in 2002 than 2000 or 2001, and this was captured in the LAI-based estimate of the backscatter (Figure 3c). The spring-time rise in backscatter at the SV-1 site was much more rapid than the rise in the LAI-based estimate of the backscatter in 2000 and 2001, but more similar in 2002 (Figure 3d).

[28] For the EN-2 site, the thawed season backscatter signal was much smaller than the signal during winter, but there was some difference in the growing season backscatter progression between the 3 years, that also corresponded to LAI seasonal and interannual variability (Figure $3 \mathrm{e}$ ). At the DB-2 site, the backscatter curve in the summers of 2000 and 2001 was broad and flat, while in 2002 it dropped off in late August and then had about a 6-week plateau in the autumn. The LAI-based estimate of the backscatter also had broad peaks but did not have the drop in 2002 (Figure 3f). The SH-1 site had low backscatter and LAI values. The March- 

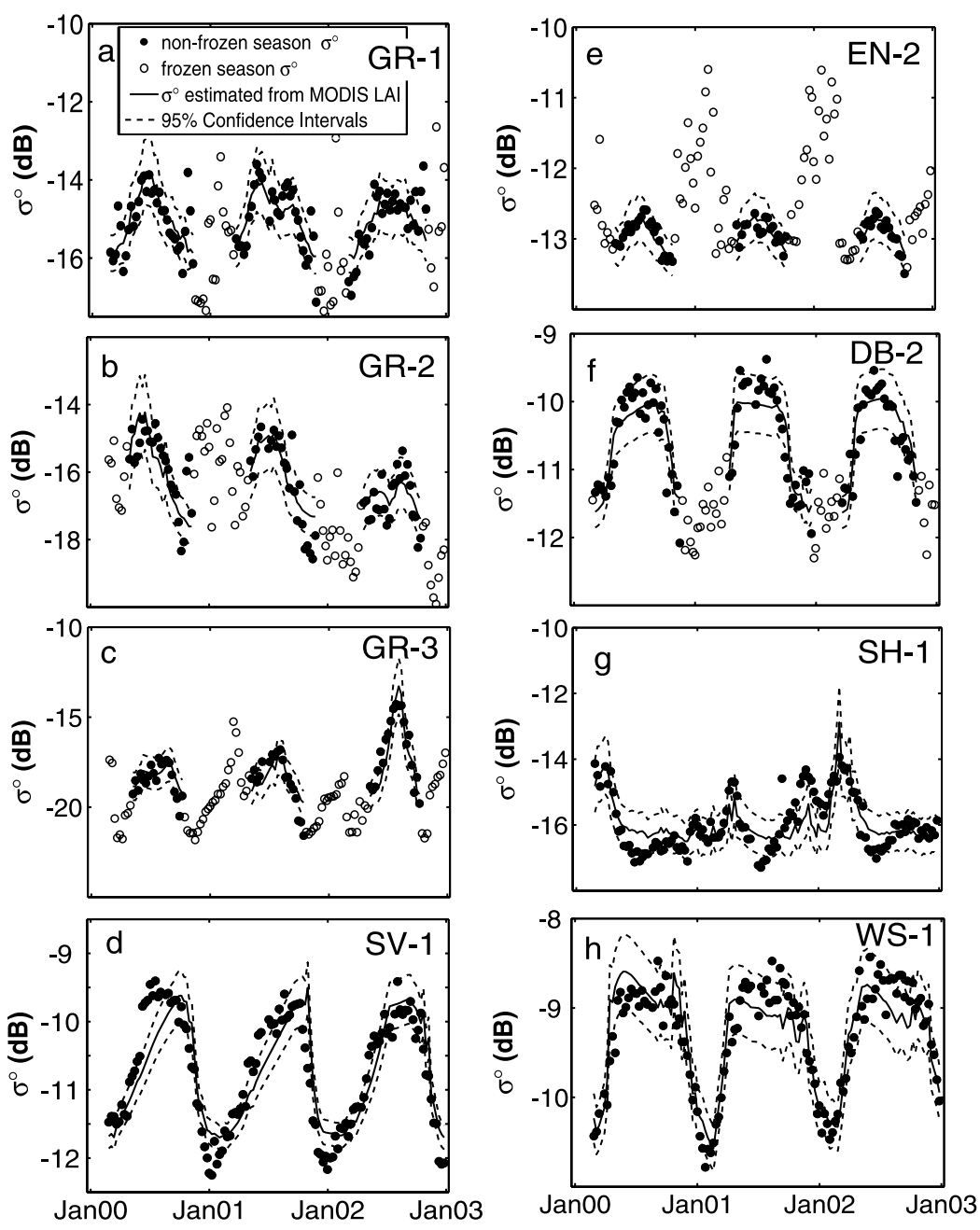

Figure 3. Three-year time series of observed 8-day composite SeaWinds backscatter $\sigma^{\circ}$ (frozen season indicated by open symbols and thawed season indicated by solid symbols) and thawed season backscatter predicted from 8-day composite MODIS LAI (solid lines) with 95\% confidence interval (dashed lines), based on linear regression fits (see Figure 1 and Table 1), for four sites with herbaceous vegetation: (a) GR-1, (b) GR-2, (c) GR-3, and (d) SV-1, and four sites with woody vegetation, (e) EN-2, (f) DB-2, (g) SH-1, and (h) WS-1. Note that all sites are $50 \mathrm{~km} \times 50 \mathrm{~km}$.

April peak was small in 2001 in both SeaWinds backscatter and the LAI-based estimate of the backscatter (Figure 3g). SeaWinds backscatter showed a steady increase from April through November 2001 that did not emerge in the LAIbased estimate of the backscatter (Figure 3g). For the WS-1 site, both SeaWinds backscatter and the LAI-based estimate of the backscatter had broad peaks from April through November, but the LAI-based estimate of the backscatter tended to drop off more during this period than the SeaWinds backscatter (Figure $3 \mathrm{~h}$ ).

[29] For the SH-4 and WS-2 sites, there was a significant phase shift between the MODIS LAI seasonal signal and the SeaWinds backscatter season signal. The SH-4 site is in central Nevada, USA, and had very low LAI values (maximum $<0.7)$ with narrow peaks $(\sim 1-2$ months) occurring in May and June of each year (Figure 4a). SeaWinds backscatter for SH-4 had a much broader peak (46 months) and backscatter increased each year as LAI was dropping from peak values (Figure 4a). This led to a negative slope in the associated linear regression relationship for these variables (Table 1 and Figure 2b). The WS-2 site is in eastern Queensland, Australia, and had low to moderate LAI values $(0.8-1.7)$ with a relatively broad peak from April-June (austral autumn) (Figure 4b). SeaWinds backscatter for WS-2 showed a similar pattern, but led the peak in LAI by several months with peak seasonal backscatter occurring from January-February (Figure 4b) during the climatological wet season [Legates and Willmott, 1990]. The resulting regression analysis of this site showed no significant relationship between SeaWinds backscatter and LAI (Table 1).

[30] The phenological timing curve fit (equation (2), section 2.1.5) successfully identified dates for the midpoint in the spring green-up and fall senescence of both SeaWinds backscatter and MODIS LAI for all 3 years at eight sites (Figure 5), and for none of the growing seasons at five sites (all EB sites and SH-2). At five sites, the curve fitting routine failed to converge for one or more, but not all, 


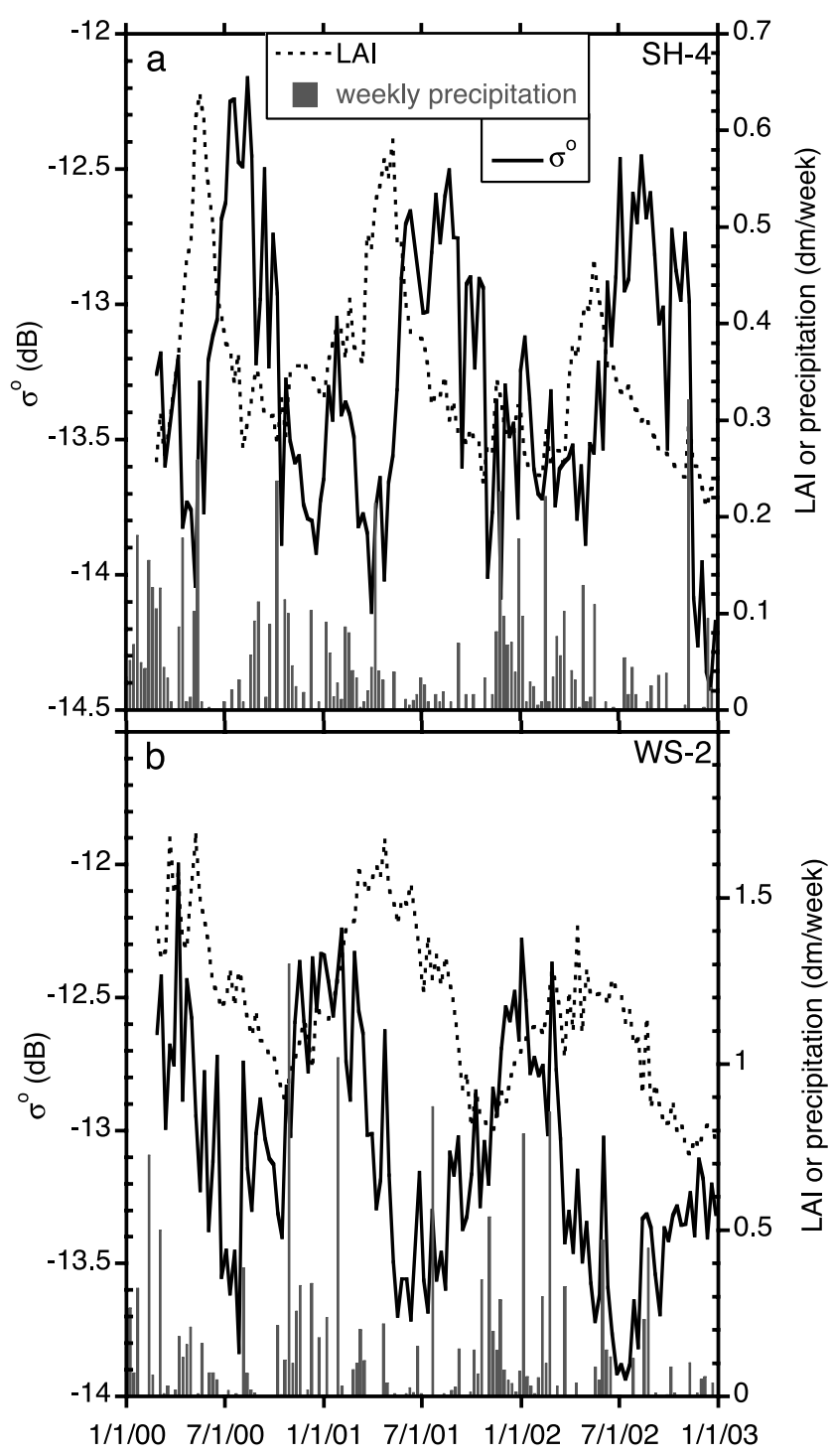

Figure 4. Three-year time series of MODIS LAI and SeaWinds backscatter for the $50 \mathrm{~km} \times 50 \mathrm{~km}$ (a) SH-4 and (b) WS-2 sites. Vertical bars are weekly precipitation from the nearest WMO-reporting weather station $(50 \mathrm{~km}$ away for SH-4 and $110 \mathrm{~km}$ away for WS-2). These two sites show a distinct phase shift between the two signals, while the other 25 sites do not.

seasons for both SeaWinds backscatter and MODIS LAI (GR-2, SH-3, SH-4, SV-2, and WS-2). Finally, for nine sites, the curve fitting routine failed to converge for one or more, but not all, seasons with the SeaWinds backscatter data, but identified dates for all seasons with MODIS LAI data (DN-1, EN-1, EN-3, EN-4, GR-1, GR-4, MF-1, MF-4, and SH-1). Overall, the curve fitting was more successful with LAI data than with backscatter data. Sites with successful fits generally had both a relatively high maximum LAI and a moderate to strong correlation between SeaWinds backscatter and MODIS LAI (Table 1).

[31] At the eight sites for which the phenological timing curve fit always identified a date, the timing of the fall senescence was generally similar for both SeaWinds back- scatter and MODIS LAI (Figure 5). However, the timing of the spring response of backscatter and LAI was approximately equivalent in all 3 years for only one site (WS-1); for the other sites the SeaWinds backscatter signal generally rose earlier than the MODIS LAI (Figure 5). At the other 14 sites where some but not all dates were identified, the timing of spring leaf-out derived from SeaWinds backscatter data occurred earlier more often than the timing identified from MODIS LAI. No clear pattern emerged in the comparison of fall senescence timing at these 14 sites. In general, there was a wider $95 \%$ confidence interval for the timing of the midpoint in spring green-up or fall senescence for SeaWinds backscatter than for MODIS LAI (Figure 5).

\subsection{Theoretical Backscatter Modeling Results}

[32] Grassland backscatter was most sensitive to soil moisture when LAI was low (Figure 6a). As leaf moisture and LAI increase, the grass canopy became a more dominant contributor to backscatter and backscatter sensitivity to soil moisture and to LAI itself diminished. Although backscatter was not sensitive to increasing LAI above about $4 \mathrm{~m}^{2}$ $\mathrm{m}^{-2}$, backscatter sensitivity to leaf moisture was still apparent at high values of LAI.

[33] For each tree canopy, backscatter was simulated for high and low values of dielectric constant $(\varepsilon)$ of the woody constituents (trunks and branches), representing respective high and low wood moisture levels (Figure 6b). Dry soil conditions and constant values for leaf moisture were applied in each case. The low biomass needleleaf canopy (black spruce) exhibits the highest backscatter sensitivity to LAI, and the lowest backscatter sensitivity to the dielectric constant of the woody constituents. Comparing this to the white spruce and poplar canopy simulations, it is apparent that as the amount of woody biomass increases, sensitivity to LAI decreases while sensitivity to woody constituent dielectric constant increases. As was the case for the grassland canopy, within a given structural class and with LAI above about $4 \mathrm{~m}^{2} \mathrm{~m}^{-2}$, most backscatter sensitivity is to moisture change in the vegetation (woody or leafy constituents) rather than to structural changes related directly to increasing LAI. The difference in backscatter behavior between the white spruce and balsam poplar canopies demonstrate the sensitivity of backscatter to vegetation branch structure.

\subsection{Regional Analysis Results}

[34] There were 829,709 land grid cells $(\sim 4.5-\mathrm{km}$ resolution) within the North American domain. Approximately 91 percent of the domain (754,269 grid cells) showed statistically valid $(\mathrm{P}<0.05)$ relationships between MODIS-derived LAI and SeaWinds backscatter growing season dynamics. Regional variability between MODIS LAI and Sea Winds backscatter dynamics appeared to follow general land cover patterns indicated by the MODIS land cover classification. There was a reasonably strong correlation $(\mathrm{R}>\sim 0.75)$ between growing season LAI and $\sigma^{\circ}$ across the eastern and central United States, southeastern Canada, and the Canadian prairies (Figure 7a). These regions are dominated in the MODIS land cover classification by cropland, deciduous broadleaf forest, cropland/other vegetation mosaic, and mixed forest (Figure 7b). Correlations were generally quite low $(\mathrm{R}<\sim 0.4)$ for the moun- 


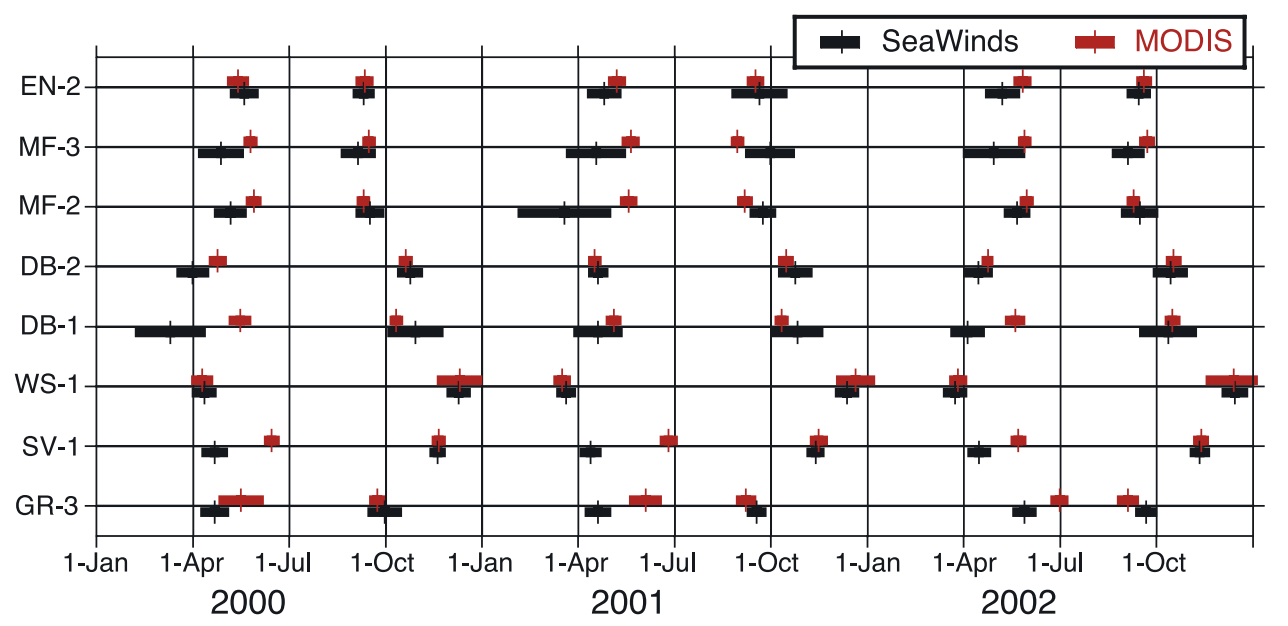

Figure 5. Onset and end of vegetation growing season as determined by fit to SeaWinds backscatter (black) and MODIS LAI (red) (see section 2.1.5 for equation). The eight sites shown were the ones where the fitting algorithm succeeded for all three springs and falls (2000-2002). Vertical lines mark midpoints of rise/fall of curve, and horizontal bars represent $95 \%$ confidence intervals around dates (see Figure 1 for sample curve fit).

tainous and western United States and Canada, boreal and arctic Canada, and most of northern Mexico (Figure 7a); these regions are dominated by evergreen needleleaf forest, closed and open shrubland, woody savanna, barren, and permanent wetland land cover types (Figure 7b). Grasslands showed intermediate and wider ranging correlations $(\mathrm{R} \sim$ $0.1-0.9$ ) (Figures $7 \mathrm{a}$ and $7 \mathrm{~b}$ ).

[35] To evaluate the correlation statistics, we reprocessed the land cover data to select only those $4.5 \mathrm{~km}$ grid cells having a single dominant land cover in their $\sim 20$ contributing MODIS pixels. We first screened out those pixels that did not pass the land cover quality control in the MODIS land cover product. We then screened out those pixels that had an IGBP land cover quality assessment of less than $50 \%$ ( $<35 \%$ for mixed forest and crop/natural vegetation mosaic) (M. Friedl, Boston University, personal communication). We then reprojected and aggregated the remaining 1-km land cover pixels to the SeaWinds data grid, and set a minimum threshold requiring that $>50 \%$ of contributing pixels were of the dominant land cover class (i.e., we excluded grid cells that had heterogeneous land cover). Finally, we screened out grid cell 8-day LAI composites that had only 5 or fewer of the $\sim 20$ potential pixels with good LAI values. In some cases, this restriction meant that there were fewer than twenty 8-day pairs of LAI and $\sigma^{\circ}$ data over the three growing seasons; in those cases no correlation was calculated. This reduced the domain to 517,686 grid cells. We then evaluated the grid cell correlations from each land cover class. Cropland, deciduous broadleaf forest, and cropland/natural vegetation mosaic all cover a significant portion of North America and all had mean and median grid cell correlations between $\sigma^{\circ}$ and LAI of about 0.75 (Table 2), and most correlations were greater than 0.7 (Figure 8). Mixed forests had a broad range of grid cell correlations (Figure 8) with a mean of about 0.75 (Table 2). Grassland grid cells had more low than high correlations (Figure 8), with a mean of about 0.5 . Woody savanna, evergreen needleleaf, and open shrubland all had generally low grid cell correlations between $\sigma^{\circ}$ and LAI, with median $\mathrm{R}^{2}$ values less than 0.3 . Several land cover classes have only a small presence $(<1 \%)$ in the MODIS land cover classification of North America: snow/ice, deciduous needleleaf forest, permanent wetland, evergreen broadleaf forest, closed shrubland, and urban/built-up (Table 2). These grid cells generally had low or highly variable correlations (Figure 8).

[36] For the broadleaf deciduous classes (deciduous broadleaf forest, cropland, cropland/natural vegetation mosaic, and grassland), higher correlations between SeaWinds backscatter and MODIS LAI $(\mathrm{R}>0.75)$ were common for grid cells that had a relatively high growing season range in LAI $\left(\mathrm{LAI}_{\max }-\mathrm{LAI}_{\min }>3 \mathrm{~m}^{2} \mathrm{~m}^{-2}\right)$, while low correlations $(\mathrm{R}<0.7)$ were common for grid cells with a lower growing season range in LAI $\left(\mathrm{LAI}_{\max }-\mathrm{LAI}_{\min }<\right.$ $2 \mathrm{~m}^{2} \mathrm{~m}^{-2}$ ) (Figure 9).

\section{Discussion}

[37] Both SeaWinds radar backscatter and MODIS optical/NIR-derived LAI arise from the interaction of electromagnetic radiation with vegetation-soil medium. However, the spectral wavelengths of these sensors differ by a factor of $\sim 10^{5}$, and thus their responses to land surface biophysics are very different. From a land cover-vegetation point of view, optical/NIR radiation interacts primarily with surface chemical composition through vibrational and electronic energy transition processes, while microwave radiation interacts more directly with surface structural properties through the dielectric properties of materials [Elachi, 1987]. The microwave dielectric constant is sensitive to molecular polarization and rotation. Since water is a polar molecule, the microwave dielectric constant is highly responsive to the amount and state of water in the material. Optical/NIR sensors are sensitive to photosynthetic leaf area associated with vegetation color, while radar sensors are sensitive to canopy structure (e.g., biomass, leaf and stem size, orientation and density) and moisture, and to soil roughness and wetness. 


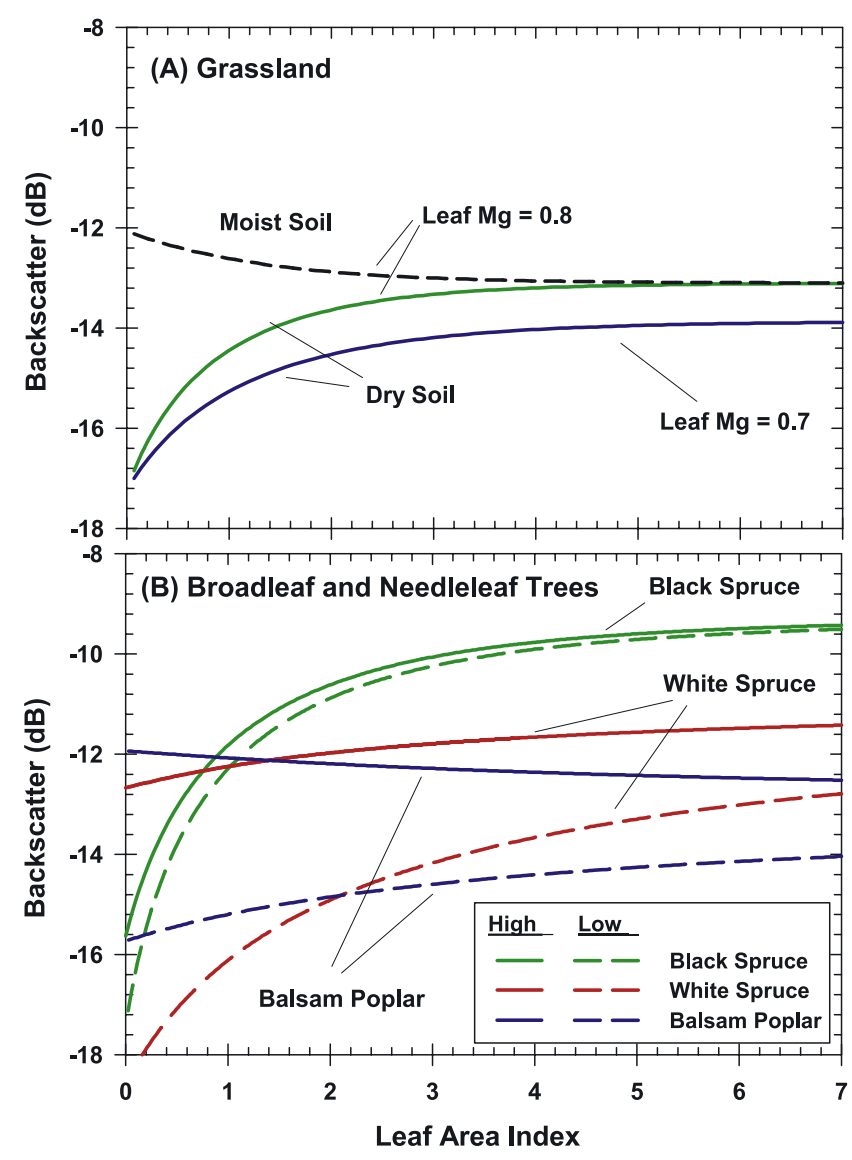

Figure 6. Modeled Ku-band VV-polarized backscatter at $54^{\circ}$ incidence angle for (a) a grassland canopy with $3 \mathrm{~cm}$ diameter leaves and (b) broadleaf deciduous (balsam poplar), high-biomass needleleaf (white spruce) and lowbiomass needleleaf (black spruce) canopies. Grassland backscatter is shown for dry and moist soil conditions and for two different leaf water content conditions. Leaf $\mathrm{Mg}$ equals water content by weight. Results for each tree canopy are derived for high and low values of the woody component dielectric constant (high $\varepsilon$, low $\varepsilon$ ). Canopy structural parameters were based on previous multiseason modeling analyses [Way et al., 1994]. Simulations were with the MIMICS model [Ulaby et al., 1990].

[38] The strong correspondence between SeaWinds backscatter and MODIS LAI at three grassland sites and at one savanna, one deciduous broadleaf, one woody savanna, one shrubland, and one evergreen needleleaf site were similar to the correspondence Hardin and Jackson [2003] observed between monthly mean SeaWinds backscatter and an AVHRR-based NDVI for savanna sites in South America. We found that correlations between leaf area and radar backscatter were generally stronger for deciduous vegetation sites (i.e., grassland and savanna, deciduous broadleaf forest but not deciduous needleleaf forest) than for evergreen vegetation sites (i.e., evergreen broadleaf and needleleaf forests). Mixed forest sites were intermediate in correlation, and the shrubland and woody shrubland site correlations were highly variable. Although Frison and Mougin [1996] did not quantify correlations, they saw similar patterns of variability in correlation between ERS
C-band backscatter and AVHRR GVI. Seasonal temperate forests, grasslands, savannas, and croplands generally had covarying signals, while tropical forests had little variability. Frison and Mougin [1996] also had one site, grassland with palms in Argentina, that had a significant phase shift between the GVI and backscatter signals.

[39] There were no strong patterns in site-level correlations when evaluated with respect to longitude, maximum growing season LAI, minimum growing season LAI, or LAI dynamic range (growing season maximum minus minimum). For the northern temperate/boreal region (35$65^{\circ} \mathrm{N}$ ) there was a moderate tendency to decreasing correlation with increasing latitude; the high-latitude sites were predominantly evergreen needleleaf or mixed forests, which had lower correlations than deciduous forests or grasslands. There was moderate tendency toward increasing correlation between backscatter and LAI as the growing season backscatter range (maximum minus minimum in $\mathrm{dB}$ ) increased; this range was highest for grassland sites (Table 1).
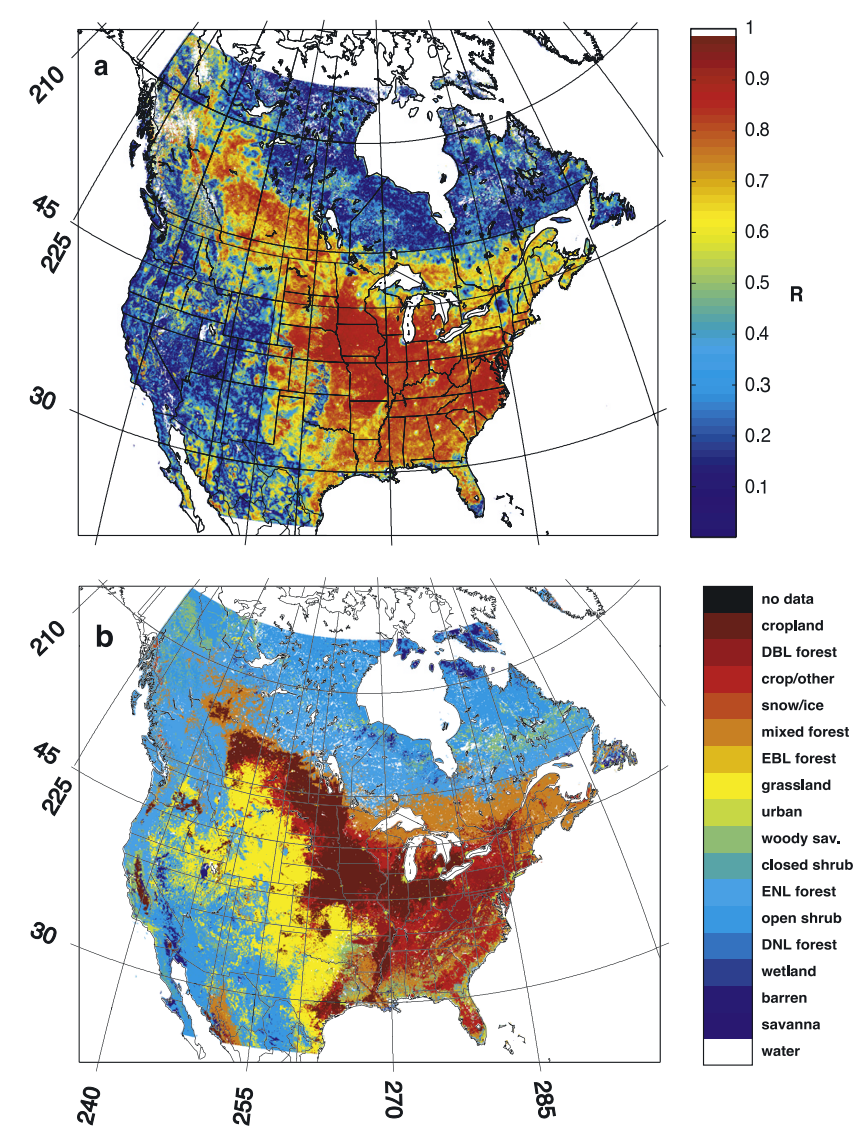

Figure 7. (a) Pearson's correlation coefficient (R) between growing season 8-day composite MODIS LAI and SeaWinds $\mathrm{Ku}$ band backscatter for January 2000 through August 2002 for each $\sim 4.5-\mathrm{km}$ pixel in the domain. The growing season for each pixel for each year was determined from the ERA-40 reanalysis temperatures (see section 2.3.3). (b) Dominant land cover for each $\sim 4.5-\mathrm{km}$ pixel in the domain, based on the 1-km MODIS land cover product MOD12Q1 (v.4), using the IGBP land cover legend (see section 2.3.2). 
Table 2. Pearson's Correlation Coefficient Between $\sigma^{\circ}$ and LAI Across North America for Grid Cells Dominated by Each Vegetation Class

\begin{tabular}{|c|c|c|c|c|}
\hline \multirow[b]{2}{*}{ Vegetation Class } & \multirow[b]{2}{*}{ Grid Cells } & \multicolumn{3}{|c|}{$\mathrm{R}$} \\
\hline & & Median & Mean & $\begin{array}{l}\text { Standard } \\
\text { Deviation } \\
\end{array}$ \\
\hline Cropland & 73,075 & 0.81 & 0.76 & 0.15 \\
\hline Deciduous broadleaf & 21,230 & 0.79 & 0.73 & 0.16 \\
\hline Crop/natural vegetation mosaic & 35,413 & 0.77 & 0.74 & 0.11 \\
\hline Mixed forest & 58,091 & 0.63 & 0.59 & 0.18 \\
\hline Evergreen broadleaf & 666 & 0.53 & 0.46 & 0.23 \\
\hline Grassland & 82,908 & 0.48 & 0.46 & 0.25 \\
\hline Urban/built-up & 3,599 & 0.42 & 0.41 & 0.25 \\
\hline Deciduous needleleaf & 4 & 0.30 & 0.24 & 0.17 \\
\hline Closed shrubland & 1,402 & 0.28 & 0.29 & 0.16 \\
\hline Woody savanna & 9,968 & 0.27 & 0.31 & 0.22 \\
\hline Evergreen needleleaf & 99,364 & 0.26 & 0.28 & 0.19 \\
\hline Open shrubland & 126,705 & 0.24 & 0.27 & 0.19 \\
\hline Permanent wetland & 111 & 0.24 & 0.25 & 0.15 \\
\hline Barren/sparse vegetation & 820 & 0.18 & 0.21 & 0.15 \\
\hline Savanna & 3,989 & 0.16 & 0.20 & 0.16 \\
\hline Water & 17,763 & 0.33 & 0.37 & 0.25 \\
\hline Unclassified $^{\mathrm{a}}$ & 240,344 & 0.45 & 0.45 & 0.27 \\
\hline
\end{tabular}

${ }^{\mathrm{a}}$ Unclassified grid cells had either heterogeneous land cover (no single class occupying more than $50 \%$ of the grid cell) or low land cover classification accuracy assessment (see text for details).
[40] Although vegetation canopies consist of more complex structures than have been incorporated in the theoretical backscatter model (e.g., heterogeneous mixtures of vegetation types and species, forest understory vegetation), MIMICS simulations demonstrate important relationships between backscatter and canopy leaf area. Model and satellite results both had a stronger sensitivity of backscatter to LAI for low LAI grassland sites (Figures $2 \mathrm{~b}$ and 5a), while sensitivities were weaker for forest landscapes (Figures 2a and 5a). Black spruce simulations had high sensitivity to LAI at low LAI values, but black spruce needles typically have a $\sim 10$-year retention time [Hom and Oechel, 1983] so actual black spruce seasonal LAI variability is quite low. This is consistent with SeaWinds observations of relatively low growing season variability $(\sim 1 \mathrm{~dB})$ in evergreen needleleaf forest backscatter.

[41] For sites with sparse vegetation (arid sites, but perhaps also cold, high-latitude sites), the backscatter signal may be driven as much or more by changes in soil moisture as by changes in vegetation canopy biomass [e.g., Wagner and Scipal, 2000; Wagner et al., 1999a; Woodhouse and Hoekman, 2000]. For example, in the dry landscapes of the Sahel, Magagi and Kerr [1997] combined optical (AVHRR)
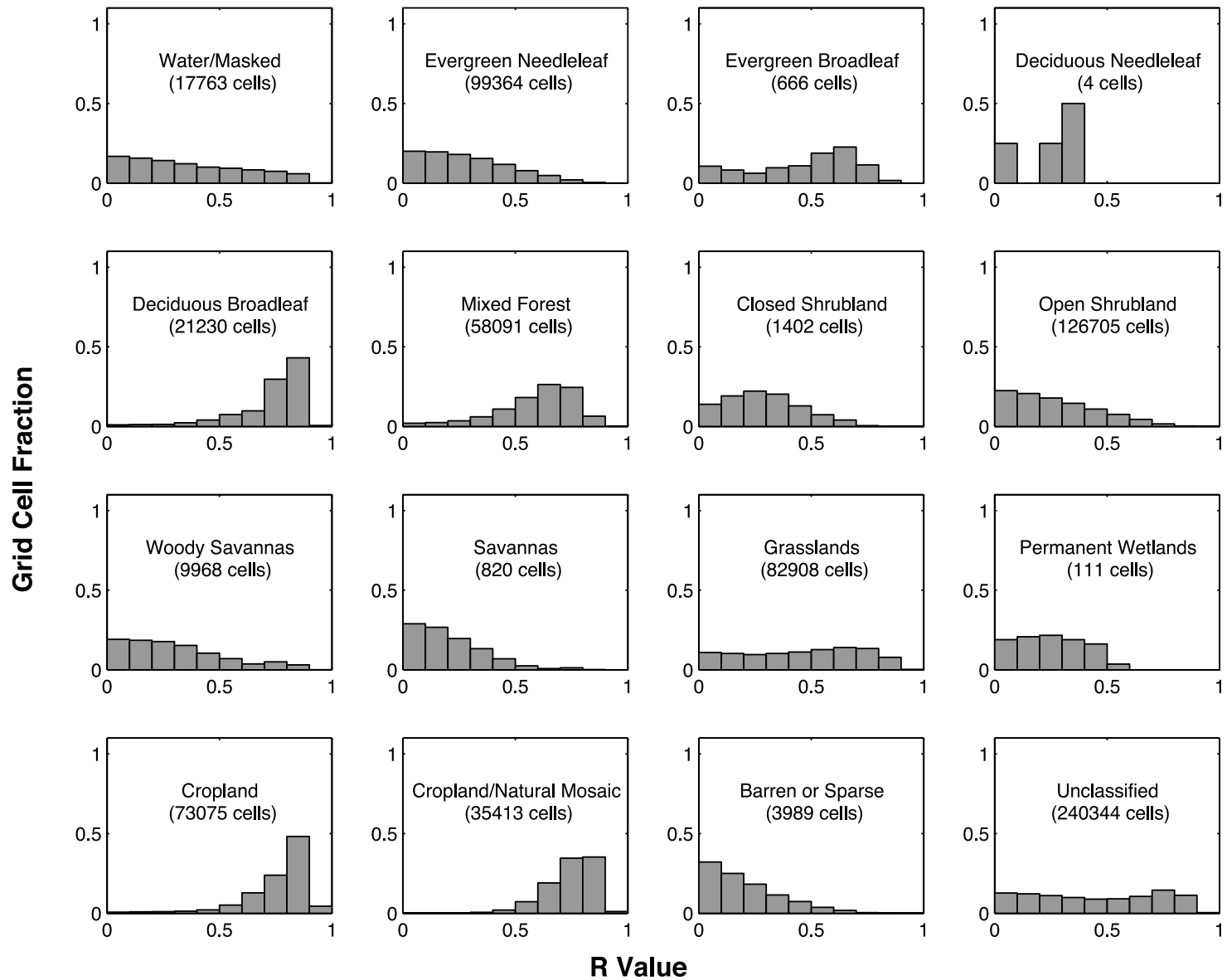

Figure 8. Histogram of Pearson's correlation coefficients (R) between growing season 8-day composite MODIS LAI and SeaWinds backscatter for January 2000 through August 2002, for each land cover type (see Figure 6). The histograms are normalized to give the fraction of total grid cells in each vegetation type for each $\mathrm{R}$ bin. In this analysis, we have included only those $\sim 4.5-\mathrm{km}$ pixels in which the dominant land cover occupies more than $50 \%$ of the pixel (see text). In all cases, correlations greater than 0.2 are significant at least to $p<0.05$. 


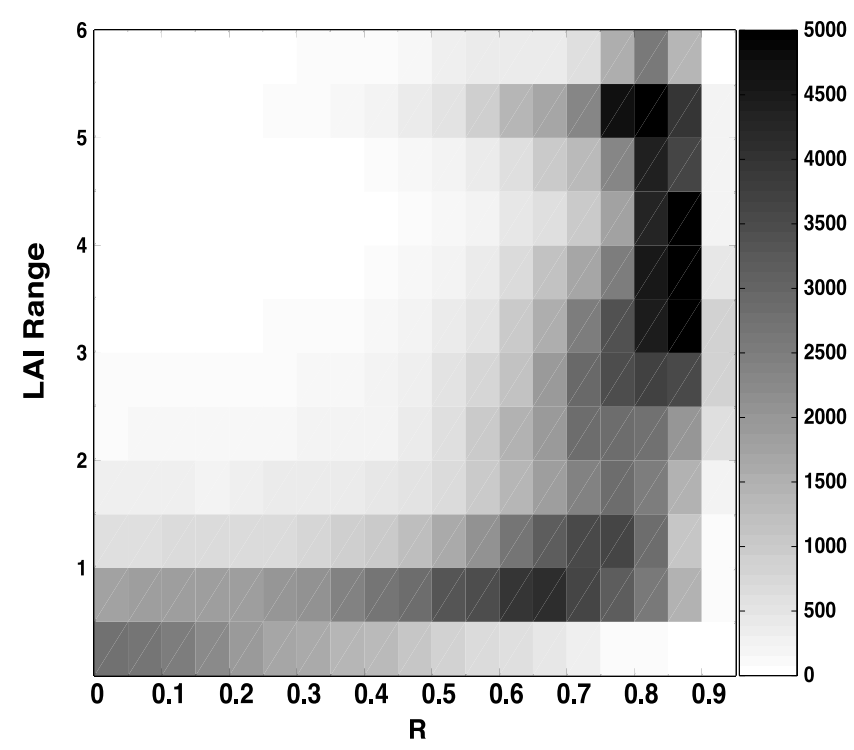

Figure 9. Two-dimensional histogram of correlations between MODIS-derived LAI and SeaWinds Ku-band backscatter for growing seasons of 2000-2002. Grid cells are binned by range in LAI (maximum minus minimum during the three growing seasons, with bins of $0.5 \mathrm{~m}^{2} \mathrm{~m}^{-2}$ ) and by Pearson's correlation coefficient ( $\mathrm{R}$, with bins of $0.05)$. The shading represents the number of grid cells that had a particular combination of LAI range and correlation, with dark shades indicating a high frequency of occurrence and light shades a low frequency. Grid cells with high correlation have a large LAI range, while grid cells with moderate to low correlation have a smaller LAI range.

and microwave (ERS C-band scatterometer) data to model the effect of vegetation on backscatter for soil moisture retrievals. Vegetation in the region is a mix of natural and agricultural (savanna, shrubland, millet, and fallow) and never completely covers the soil. They concluded that for incidence angles of $40-46^{\circ}$, vegetation and soil contributions to the backscatter were comparable during the wet season when the vegetation was at maximum biomass. Our MIMICS simulations also showed strong backscatter sensitivity to soil moisture at low LAI for nonwoody vegetation (Figure 5a). Soil moisture effects could be responsible for some of the seasonality observed at sites and in regions with low LAI. The observed phase shift between LAI and backscatter peaks at two dry sites (SH-4 and WS-2 in Figure 4), may be due differences in the seasonal dynamics of soil moisture, vegetation moisture, and the canopy LAI. A counterargument to that explanation is that the observed seasonal backscatter signal is an increase that is sustained for several months; if soils are relatively wet for months, vegetation generally will grow and LAI dynamics should reflect this.

[42] Although there was variability in both backscatter and LAI for the evergreen broadleaf forest sites (tropical rain forests), there was no correlation between the two signals. Seasonal LAI variability for these sites was generally small (i.e., \pm 1 LAI unit) relative to mean LAI values $\left(\sim 5 \mathrm{~m}^{2} \mathrm{~m}^{-2}\right)$. Backscatter seasonal variability was also smaller $(\sim 1 \mathrm{~dB})$ for evergreen broadleaf forests than most other sites, while backscatter itself (generally -8 to $-9 \mathrm{~dB}$ ) was higher than all other vegetation types (generally -10 to $-20 \mathrm{~dB}$ ). Woodhouse et al. [1999] saw seasonal variation in ERS C-band backscatter over 10 months for a single tropical rain forest site in Guyana, which they correlated to local precipitation. However, the seasonal backscatter variation was only $0.4 \mathrm{~dB}$, and with only a single site analyzed, there was no indication if this pattern would be detectable at larger scales.

[43] Extracting regional-scale phenological timing (spring leaf flush and fall senescence) has been done with optical remote sensing for boreal and temperate forests [e.g., Zhang et al., 2003, 2004; Jenkins et al., 2002; White et al., 1997] and for wet-dry seasonal landscapes [e.g., Davenport and Nicholson, 1993]. We are not aware of any previous attempts to assess seasonal vegetation phenology with microwave backscatter data. The earlier onset of the increase in backscatter relative to LAI at many sites (Figure 5) implies that the springtime backscatter signal is responding to a different characteristic of the land surface than the optical signal. On the basis of the MIMICS simulations, the observed earlier springtime rise in backscatter relative to the rise in LAI in woody vegetation may be caused by a springtime increase in the dielectric constant of trunks and branches, driven by an increase in the associated liquid water content of these components that precedes leafout. For nonwoody vegetation, this effect could be associated with a springtime increase in surface moisture preceding significant vegetative growth. The strong link between available liquid water and vegetative growth makes it difficult, and perhaps less important, to separate the two effects. Soil moisture, however, can vary on short timescales relative to the vegetation canopy [e.g., Wagner and Scipal, 2000]. Furthermore, vegetation dielectric has been observed to increase substantially shortly after rainfall events [McDonald et al., 1999, 2002]. Thus it may be that under some conditions short-term changes driven by episodic precipitation (e.g., convective storms) will influence backscatter variability but not LAI. This, along with freeze-thaw sensitivity of the radar backscatter, may account for the wider confidence intervals for SeaWinds phenological timing, particularly for temperate/ boreal forest sites (Figure 5).

[44] In the regional analysis, deciduous broadleaf vegetation grid cells that have a significant range in LAI over the growing season (crops, deciduous trees, crop/other mosaic, some grasslands) consistently have good correlations between growing season LAI and backscatter time series, implying that backscatter responds to growing season canopy dynamics of these vegetation types in a predictable and robust way. As the landscape becomes more evergreen (mixed and needleleaf forests in the north and west; subtropical vegetation along the Gulf coast) or more arid (open shrubland, arid grassland, and barren land in the west and southwest) the correlations drop quickly to $\mathrm{R}<0.4$. For these regions, either the seasonal variability in the signal (LAI or backscatter) is not large relative to higher frequency variability (perhaps because of moisture variability for SeaWinds and atmospheric variability for MODIS), or the seasonal signals are not in phase. However, Frolking et al. [2005] found that strong correlations for $10^{3}-10^{4} \mathrm{~km}^{2}$ regions of semiarid grasslands in southern Alberta, eastern Colorado, and the western Dakotas, was due to growing 
season LAI and backscatter covarying interannually, driven by interannual variability in precipitation.

\section{Conclusions}

[45] Site-level and continental-scale analyses of SeaWinds radar backscatter and MODIS LAI data for nonfrozen periods from 2000 to 2002 have demonstrated that SeaWinds backscatter responds to growing season canopy dynamics in a manner often similar, but not identical, to the response of LAI derived from the MODIS optical/NIR instrument. Both data sets show a clear growing season signal for most deciduous broadleaf vegetation. Several lines of evidence support this conclusion:

[46] 1. The growing season SeaWinds backscatter and MODIS LAI time series (2000-2002) for $50 \mathrm{~km} \times 50 \mathrm{~km}$ sites with seasonally deciduous broadleaf vegetation were significantly correlated for sites around the world $\left(\mathrm{R}^{2} \sim\right.$ 0.25-0.82; Table 1 and Figure 3).

[47] 2. There were large, spatially coherent patterns in the correlation between thawed season backscatter and LAI across North America, and these were very similar to spatial patterns of MODIS-derived land cover (Figure 7).

[48] 3. Forward modeling of VV-polarized $14 \mathrm{GHz}$ microwave backscatter for several vegetation types with a range of LAI values shows that observed patterns of SeaWinds backscatter response to growing season canopy dynamics are generally consistent with scattering theory (Figures 2 and 6).

[49] 4. Phenological curve-fitting to SeaWinds backscatter and MODIS LAI time series had similar degrees of success. The specified onset of the growing season arc generally occurred earlier for the SeaWinds instrument than the MODIS instrument (Figure 5). This may be associated with a general wetting of soil and woody tissues, which generates a backscatter response, before significant foliar growth, which generates a MODIS LAI response.

[50] 5. In addition, Frolking et al. [2005] found similar spatial and temporal patterns in interannual variability (2000-2004) of mid-growing season SeaWinds backscatter and MODIS LAI across North America; grasslands of the western Great Plains had the largest variability and that variability was consistent with variability in precipitation.

[51] Optical/NIR and microwave remote sensing instruments are sensitive to somewhat different, though often related, surface characteristics, and therefore do not detect identical dynamics in vegetation/surface seasonality. The standard view of vegetation phenology is the seasonal trajectory of photosynthetic biomass (i.e., LAI). The seasonality of the surface characteristics that influence microwave backscatter (canopy structure and mass and the amount and phase of water in the vegetation and soil) often parallels LAI seasonality, and reveals different, but potentially complimentary information about the phenology signal.

[52] Optical/NIR and microwave remote sensing provide completely independent measures of vegetation/land surface and its seasonal dynamics. Active microwave remote sensing is less compromised by variability in the atmosphere (e.g., clouds, smoke and haze [Vermote et al., 2002; Friedl et al., 2002; Zhao et al., 2005]), and has higher temporal resolution. Optical/NIR remote sensing is less compromised by short-term variability in surface moisture content, and has higher spatial resolution. Identifying large, spatially coherent regions with high correlation in the seasonality of coincident MODIS and SeaWinds remote sensing observations indicate regions where the surface properties covary, increasing confidence in the interpretation of both data sets. Large, spatially coherent regions with low correlation invite further analysis. In some cases (e.g., evergreen broadleaf vegetation), neither instrument detects much seasonality, and the lack of correlation is to be expected, as the high frequency variability of each instrument has different causes. In cases where both instruments detect seasonality, they are both measuring a real variability in surface characteristics, and it needs to be understood why these characteristics do not covary. A more complete picture of the phenology of the land surface may be found through a combined analysis of the optical/NIR and microwave data.

[53] Acknowledgments. This study was supported by NASA's Terrestrial Ecology Program through grant NAG5-11256 and by the NASA Interdisciplinary Science Program through grant NG04GH75G. Resolutionenhanced SeaWinds backscatter data were provided through the NASA Scatterometer Climate Record Pathfinder project at Brigham Young University (http://www.scp.byu.edu). Portions of this work were carried out at the Jet Propulsion Laboratory, California Institute of Technology, under contract with NASA. Three anonymous reviewers provided careful reading and helpful comments that improved the manuscript.

\section{References}

Abdel-Messeh, M., and S. Quegan (2000), Variability in ERS scatterometer measurements over land, IEEE Trans. Geosci. Remote Sens., 38, $1767-$ 1776 .

Cihlar, J., J. M. Chen, Z. Li, F. Huang, R. Latifovic, and R. Dixon (1998), Can interannual land surface signal be discerned in composite AVHRR data?, J. Geophys. Res., 103, 23,163-23,172.

Data Assimilation Office (2002), Algorithm Theoretical Basis Document, NASA Goddard Space Flight Cent., Greenbelt, Md.

Davenport, M. L., and S. E. Nicholson (1993), On the relation between rainfall and the Normalized Difference Vegetation Index for diverse vegetation types in East Africa, Int. J. Remote Sens., 14, 2369-2389.

Du, Y., F. T. Ulaby, and M. C. Dobson (2000), Sensitivity to soil moisture by active and passive microwave sensors, IEEE Trans. Geosci. Remote Sens., 38, 105-114.

Early, D. S., and D. G. Long (1996), Error characteristics of the SIR resolution enhancement algorithm, Proc. IGARSS '96, 1, 124-126.

Early, D. S., and D. G. Long (2001), Image reconstruction and enhanced resolution imaging from irregular samples, IEEE Trans. Geosci. Remote Sens., 39, 291-302.

Elachi, C. (1987), Introduction to the Physics and Techniques of Remote Sensing, 432 pp., John Wiley, Hoboken, N. J.

Fitzjarrald, D. R., O. A. Acevedo, and K. E. Moore (2001), Climatic consequences of leaf presence in the eastern United States, J. Clim., 14, $598-614$

Friedl, M. A., et al. (2002), Global land cover mapping from MODIS: Algorithms and early results, Remote Sens. Environ., 83, 287-302.

Frison, P. L., and E. Mougin (1996), Monitoring global vegetation dynamics with ERS-1 wind scatterometer data, Int. J. Remote Sens., 17, $3201-3218$

Frolking, S., M. Fahnestock, T. Milliman, K. McDonald, and J. Kimball (2005), Interannual variability in North American grassland biomass/productivity detected by SeaWinds scatterometer backscatter, Geophys. Res. Lett., 32(21), L21409, doi:10.1029/2005GL024230.

Goward, S. N., C. J. Tucker, and D. G. Dye (1985), North American vegetation patterns observed with the NOAA advanced very high resolution radiometer, Vegetatio, 64, 3-14.

Hardin, P. J., and M. W. Jackson (2003), Investigating SeaWinds terrestrial backscatter: Equatorial savannas of South America, Photogramm. Eng. Remotr Sens., 69, 1243-1254.

Hicke, J. A., G. P. Asner, J. T. Randerson, C. Tucker, S. Los, R. Birdsey, J. C. Jenkins, C. Field, and E. Holland (2002), Satellite-derived increases in net primary productivity across North America, 1982-1998, Geophys. Res. Lett., 29(10), 1427, doi:10.1029/2001GL013578.

Hom, J. L., and W. C. Oechel (1983), The photosynthetic capacity, nutrient content, and nutrient use efficiency of different needle age-classes of 
black spruce (Picea mariana) found in interior Alaska, Can. J. For. Res., $13,834-839$

Jenkins, J. P., B. H. Braswell, S. E. Frolking, and J. D. Aber (2002), Detecting and predicting spatial and interannual patterns of temperate forest springtime phenology in the eastern U.S., Geophys. Res. Lett. 29(24), 2201, doi:10.1029/2001GL014008.

Keeling, C. D., R. B. Bascatow, A. F. Carter, S. C. Piper, T. P. Whorf, M. Heimann, W. G. Mook, and H. Roeloffzen (1989), A three-dimensional model of atmospheric $\mathrm{CO} 2$ transport based on observed winds: 1. Analysis of observational data, in Aspects of Climate Variability in the Pacific and the Western Americas, Geophys. Monogr. Ser., vol. 55 , edited by D. H. Peterson, pp. 165-236, AGU, Washington, D. C.

Kimball, J. S., K. C. McDonald, S. Frolking, and S. W. Running (2004a), Radar remote sensing of the spring thaw transition across a boreal landscape, Remote Sens. Environ., 89, 163-175.

Kimball, J. S., K. C. McDonald, S. W. Running, and S. Frolking (2004b), Satellite radar remote sensing of seasonal growing seasons for boreal and subalpine evergreen forests, Remote Sens. Environ., 90, 243-258.

King, M. D., and R. Greenstone (Eds.) (1999), EOS Reference Handbook: A Guide to NASA's Earth Science Enterprise and the Earth Observing System, NASA Doc. NP-1999-08-134-GSFC, 361 pp.

Lechowicz, M. J. (2001), Phenology, in Encyclopedia of Global Environmental Change, vol. 2, The Earth System: Biological and Ecological Dimensions of Global Environmental Change, pp. 461-465, John Wiley, Hoboken, N. J.

Legates, D. R., and C. J. Willmott (1990), Mean seasonal and spatial variability in gauge-corrected, global precipitation, Int. J. Climatol., 10 , $111-127$.

Magagi, R. D., and Y. H. Kerr (1997), Retrieval of soil moisture and vegetation characteristics by use of ERS-1 wind scatterometer over arid and semi-arid areas, J. Hydrol., 188-189, 361-384.

McDonald, K. C., and J. S. Kimball (2005), Hydrological application of remote sensing: Freeze-thaw states using both active and passive microwave sensors, in Encyclopedia of Hydrological Sciences, vol. 2, part 5 , Remote Sensing, edited by M. G. Anderson and J. J. McDonnell, pp. 783-798, John Wiley, Hoboken, N. J.

McDonald, K. C., and F. T. Ulaby (1993), Radiative transfer modeling of discontinuous tree canopies at microwave frequencies, Int. J. Remote Sens., 14, 2097-2128.

McDonald, K. C., M. C. Dobson, and F. T. Ulaby (1990), Using MIMICS to model L-band multi-angle and multi-temporal backscatter from a walnut orchard, IEEE Trans. Geosci. Remote Sens., 28, 477-491.

McDonald, K. C., M. C. Dobson, and F. T. Ulaby (1991), Modeling multifrequency diurnal backscatter from a walnut orchard, IEEE Trans. Geosci. Remote Sens., 29, 852-863.

McDonald, K. C., R. Zimmermann, J. B. Way, and W. Chun (1999), Automated instrumentation for continuous monitoring of the dielectric properties of woody vegetation: System design, implementation and selected in situ measurements, IEEE Trans. Geosci. Remote Sens., 37, $1880-1894$

McDonald, K. C., R. Zimmermann, and J. Kimball (2002), Diurnal and spatial variation of xylem dielectric constant in Norway Spruce (Picea abies [L.] Karst.) as related to microclimate, xylem sap flow, and xylem chemistry, IEEE Trans. Geosci. Remote Sens., 40, $2063-2082$.

McDonald, K. C., J. S. Kimball, E. Njoku, R. Zimmermann, and M. S. Zhao (2004), Variability in springtime thaw in the terrestrial high latitudes: Monitoring a major control on the biospheric assimilation of atmospheric $\mathrm{CO}_{2}$ with spaceborne microwave remote sensing, Earth Interact., $8,1-23$.

Moulin, S., L. Kergoat, N. Viovy, and G. Dedieu (1997), Global-scale assessment of vegetation phenology using NOAA/AVHRR satellite measurements, J. Clim., 10, 1154-1170.

Myneni, R. B., C. D. Keeling, C. J. Tucker, G. Asrar, and R. R. Nemani (1997), Increased plant growth in the northern high latitudes from 1981 to 1991, Nature, 386, 698-702.

Myneni, R. B., C. J. Tucker, G. Asrar, and C. D. Keeling (1998), Interannual variations in satellite-sensed vegetation index data from 1981 to 1991, J. Geophys. Res., 103, 6145-6160.

Myneni, R. B., et al. (2002), Global products of vegetation leaf area and fraction absorbed PAR from year one of MODIS data, Remote Sens. Environ., 83, 214-231.

Nemani, R. R., C. D. Keeling, H. Hashimoto, W. M. Jolly, S. C. Piper, C. J. Tucker, R. B. Myneni, and S. W. Running (2003), Climate-driven increases in global terrestrial net primary production from 1982-1999, Science, 300, 1560-1563.

Nghiem, S. V., and W.-Y. Tsai (2001), Global snow cover monitoring with spaceborne Ku-band scatterometer, IEEE Trans. Geosci. Remote Sens., $39,2118-2134$
Potter, C., S. Klooster, R. Myneni, V. Genovese, P.-N. Tan, and V. Kumar (2003), Continental-scale comparisons of terrestrial carbon sinks estimated from satellite data and ecosystem modeling 1982-1998, Global Planet. Change, 39, 201-213.

Rawlins, M., K. McDonald, S. Frolking, R. Lammers, M. Fahnestock, J. Kimball, and C. Vorosmarty (2005), Remote sensing of pan-Arctic snowpack thaw using the SeaWinds scatterometer, J. Hydrol., 312, $211-294$.

Rignot, E., J. B. Way, K. McDonald, L. Viereck, C. Williams, P. Adams, C. Payne, W. Wood, and J. Shi (1994), Monitoring environmental conditions in taiga forests using ERS-1 SAR, Remote Sens. Environ., 49, $145-154$.

Sellers, P. J. (1985), Canopy reflectance, photosynthesis and transpiration, Int. J. Remote Sens., 6, 1335-1372.

Slayback, D. A., J. E. Pinzon, S. O. Los, and C. J. Tucker (2003), Northern Hemisphere photosynthesis trends 1982-1999, Global Change Biol., 9, $1-15$.

Tucker, C. J. (1979), Red and photographic infrared linear combinations for monitoring vegetation, Remote Sens. Environ., 8, 127-150.

Tucker, C. J., D. A. Slayback, J. E. Pinzon, S. O. Los, R. B. Myneni, and M. G. Taylor (2001), High northern latitude NDVI and growing season trends from 1982 to 1999, Int. J. Biometeorol., 45, 284-290.

Ulaby, F. T., and C. Elachi (Eds.) (1990), Radar Polarimetry for Geoscience Applications, Artech House, Norwood, Mass.

Ulaby, F. T., R. K. Moore, and A. K. Fung (1982), Microwave Remote Sensing-Active and Passive, vol. II, Radar Remote Sensing and Surface Scattering and Emission Theory, 607 pp., Addison-Wesley, Boston, Mass.

Ulaby, F. T., K. Sarabandi, K. McDonald, M. Whitt, and M. C. Dobson (1990), Michigan microwave canopy scattering model, Int. J. Remote Sens., 11, 1223-1254.

Vermote, E. F., N. Z. El Saleous, and C. O. Justice (2002), Atmospheric corrections of MODIS data in the visible to middle infrared: First results, Remote Sens. Environ., 83, 97-111.

Wagner, W., and K. Scipal (2000), Large-scale soil moisture mapping in western Africa using the ERS scatterometer, IEEE Trans. Geosci. Remote Sens., 38, 1777-1782.

Wagner, W., J. Noll, M. Borgeaud, and H. Rott (1999a), Monitoring soil moisture over the Canadian Prairies with the ERS, IEEE Trans. Geosci. Remote Sens., 37, 206-216.

Wagner, W., G. Lemoine, M. Borgeaud, and H. Rott (1999b), A study of vegetation cover effects on ERS scatterometer data, IEEE Trans. Geosci. Remote Sens., 37, 938-948.

Way, J. B., E. Rignot, K. McDonald, R. Oren, R. Kwok, G. Bonan, M. C. Dobson, L. Viereck, and J. E. Roth (1994), Evaluating the type and state of Alaska taiga forests with imaging radar for use in ecosystem flux models, IEEE Trans. Geosci. Remote Sens., 32, 353-370.

White, M. A., P. E. Thornton, and S. W. Running (1997), A continental phenology model for monitoring vegetation responses to interannual variability, Global Biogeochem. Cycles, 11, 217-234.

Wismann, V. (2000), Monitoring of seasonal thawing in Siberia with ERS scatterometer data, IEEE Trans. Geosci. Remote Sens., 38, 1804-1809.

Woodhouse, I. H., and D. H. Hoekman (2000), A model-based determination of soil moisture trends in Spain with the ERS-scatterometer, IEEE Trans. Geosci. Remote Sens., 38, 1783-1793.

Woodhouse, I. H., J. J. van der Sanden, and D. H. Hoekman (1999), Scatterometer observations of seasonal backscatter variation over tropical rain forest, IEEE Trans. Geosci. Remote Sens., 37, 859-861.

Zhang, X. Y., M. A. Friedl, C. B. Schaaf, A. H. Strahler, J. C. F. Hodges, F. Gao, B. C. Reed, and A. Huete (2003), Monitoring vegetation phenology using MODIS, Remote Sens. Environ., 84, 471-475.

Zhang, X. Y., M. A. Friedl, C. B. Schaaf, and A. H. Strahler (2004), Climate controls on vegetation phenological patterns in northern midand high-latitudes inferred from MODIS data, Global Change Biol., $10,1133-1145$

Zhao, M., F. A. Heinsch, R. R. Nemani, and S. W. Running (2005), Improvements of the MODIS terrestrial gross and net primary production global dataset, Remote Sens. Environ., 95, 164-176.

M. Fahnestock, S. Frolking, and T. Milliman, Institute for the Study of Earth, Oceans and Space, University of New Hampshire, 39 College Road, Durham, NH 03824, USA. (steve.frolking@unh.edu)

J. Kimball, Flathead Lake Biological Station, Division of Biological Sciences, University of Montana, Missoula, MT 59812, USA.

K. McDonald, Jet Propulsion Laboratory, California Institute of Technology, Pasadena, CA 91109, USA.

M. Zhao, Numerical Terradynamic Simulation Group, University of Montana, Missoula, MT 59812, USA. 